\title{
María de Fonseca (c. I486-I52I) \\ and the Marquis of Zenete (I473-I523): Aristocratic Rebels and Patrons of Renaissance Culture
}

\author{
Roger Boase \\ Queen Mary, University of London \\ R.Boase@qmul.ac.uk \\ http://orcid.org/OOOO-OOOI-68OI-8598
}

Received 29/o8/20I5; accepted IO/O2/20I6

DOI Io.7203/MCLM.3.6856

\begin{abstract}
The story of Rodrigo Díaz de Vivar y Mendoza, Marquis of Zenete, Cardinal Mendoza’s eldest son, and his second wife María de Fonseca would furnish a writer with ample material for an exciting novel and certainly deserves to be better known, especially in the Anglophone world. Among other things, this article sheds some light on the vulnerable status of women in late medieval and Renaissance Spain at a time when noble ladies had greater educational opportunities, and casts doubt on the alleged role played by Queen Isabel in championing the freedom and the rights of women; and it discusses how the Marquis of Zenete expressed his personality through jousting invenciones and inscriptions in Latin on the walls of his palace of La Calahorra, and introduced many features of Italian art and architecture into Spain almost in defiance of the status quo. The author explains why the Marquis wrote the words NULA SECUNDA on a harp that he gave as a present to Prince Juan. The possible significance of a quotation by Ovid formerly in the Salón de los Marqueses in the Palace of La Calahorra is discussed, and attention drawn to the appearance of the Fonseca sisters in the anonymous

Carajicomedia.
\end{abstract}

KEYWORDS

Spanish society; Castilian culture fifteenth to sixteenth centuries: clandestine marriage; principle of consent in marriage; Rodrigo Díaz de Vivar Marquis of Zenete; María de Fonseca; Cardinal Mendoza; Marina de Aragón Princess of Salerno; Mencía de Lemos; Diego de Quiñones; Quirós; Germanies' revolt; palace of La Calahorra; Coca; Alaejos; Carajicomedia; Cancionero general; Lucio Marineo Siculo; Lluís de Milà; Paolo de San Leocadio; Laodamia; Laudomia; Ovid; Fortune;

Mars and Venus.

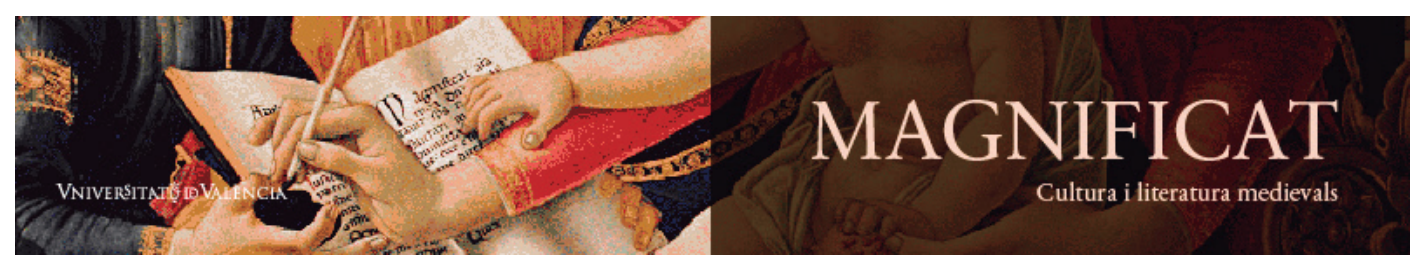

Magnificat Cultura i Literatura Medievals 3, 20I6, 37-66. http://ojs.uv.es/index.php/MCLM

ISSN $2386-8295$ 
RESUMEN

La historia de Rodrigo Díaz de Vivar, marqués de Zenete, el hijo primogénito del Cardenal Mendoza, y su segunda mujer María de Fonseca podría proporcionar a un escritor material más que suficiente para escribir una novela apasionante, y ciertamente merece ser mejor conocida, sobre todo en el mundo anglófono. Entre otras cosas, este artículo arroja algo de luz sobre la condición social vulnerable de la mujer en España durante la baja Edad Media y el Renacimiento cuando había más oportunidades educativas para las damas de la nobleza, y pone en duda el supuesto papel jugado por la reina Isabel en defensa de la libertad y los derechos de la mujer; y discute cómo el marqués de Zenete expresó su personalidad en letras e invenciones, y en inscripciones en latín sobre los paredes de su palacio de La Calahorra, e introdujo en España muchas características del arte y arquitectura italianos, casi como desafío al status quo. El autor da una explicación a las palabras NULA SECUNDA escritas sobre un arpa que el marqués dio como regalo al príncipe don Juan. Se discute la posible significación de una citación de Ovidio antiguamente en el Salón de los Marqueses en el Palacio de La Calahorra, y se llama la atención sobre la presencia de las hermanas Fonseca en la anónima Carajicomedia.

PALABRAS CLAVE

Sociedad española; cultura castellana siglos XV-XVI; matrimonio clandestino; principio de consentimiento en el matrimonio; Rodrigo Díaz de Vivar marqués de Zenete; María de Fonseca; cardenal Mendoza; Marina de Aragón Princesa de Salerno; Mencía de Lemos; Diego de Quiñones; Quirós; revuelta de las Germanías; palacio de La Calahorra; Coca; Alaejos; Carajicomedia; Cancionero general; Lucio Marineo Siculo; Luis de Milán; Paolo de San Leocadio; Laodamia; Laudomia; Ovidio; Fortuna; Marte y Venus;

Roger Boase. 20I6. 'María de Fonseca (c. I486-I52I) and the Marquis of Zenete (I473-I523): Aristocratic Rebels and Patrons of Renaissance Culture', Magnificat Cultura i Literatura Medievals, $3: 37-66$ (c) BY 


\section{$\partial *$}

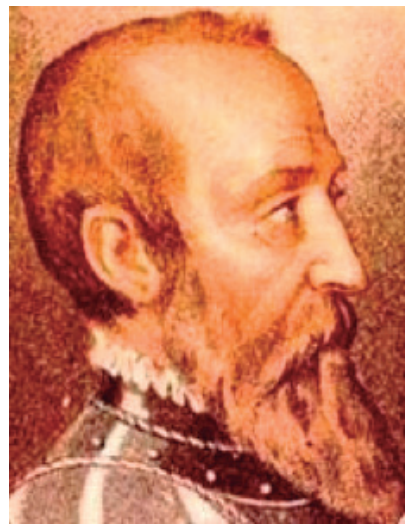

Fig. I. Rodrigo Díaz de Vivar, Marquis of Zenete (CCo r.o Public domain).

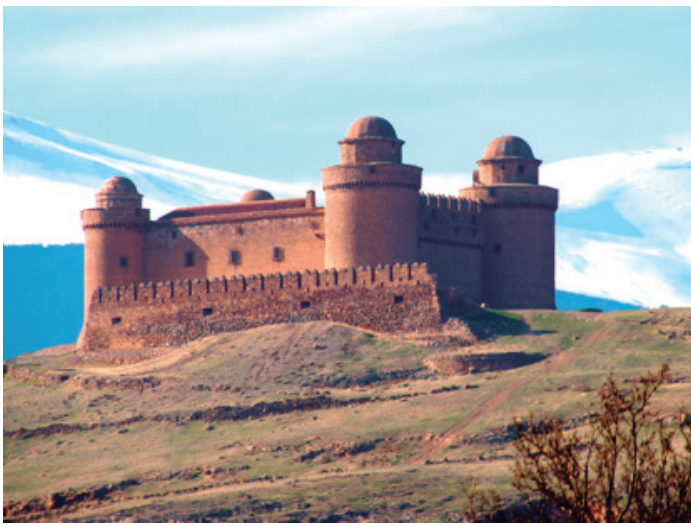

Fig. 2. Castle of La Calahorra,

CC-BY-NC-ND Miguel Bueno Jiménez [http:// miguelbueno.blogspot.com/]

$\mathrm{T}$ his is an unusual and romantic story of two aristocrats and patrons of the arts who finally succeeded in marrying and pursuing their dreams, despite determined opposition from both Queen Isabel and the young woman's father. Our knowledge about this story is still fragmented and incoherent. ${ }^{\mathrm{I}}$ There are two main reasons for this. First of all, there is no full-length contemporary biography of the Marquis of Zenete and the section assigned to him in Gonzalo Fernández de Oviedo's Batallas y quinquagenas is scarcely legible. Secondly, scholars have tended to approach this subject from the perspective of their own particular discipline: historians provide us with the bare facts of their lives, although they do not even agree about when the couple were born or when they died; art historians have made many discoveries about the architecture of the palace of La Calahorra that the marquis built near Granada, and about his house and gardens at Alcosser, near Alberic, south of Valencia; scholars of private libraries have catalogued the books that he owned; while historians with an interest in social history have studied María de Fonseca's forced marriage to her first cousin Pedro Ruiz de Fonseca as an example of the violence experienced by women, even women of the nobility, during this period of European history. I have attempted to give a fuller picture by summarising the research that has been done and by adding what may be gleaned about this story from the Cancionero general and elsewhere. ${ }^{2}$

María de Fonseca y Toledo was born into one of the wealthiest and most powerful families of late medieval Spain. ${ }^{3}$ It was a noble and ecclesiastical family of Portuguese and converso ancestry with artistic and intellectual pretensions and with a reputation for amorous and political intrigue. She

I. I am indebted to the late Dr José Luis García de Paz, who generously compiled a bibliography on this topic when I wrote to ask him for his advice in October 20o9. Only recently, when I attempted to send him an email message, did I discover that he had died suddenly on 2I October 2OI3 at the age of 54 . I am also very grateful to Frank Newsum and Rosanna Cantavella for their comments and advice.

2. There is inevitably some overlap here with the account of the life and works of the Marquis of Zenete in Perea Rodríguez 2007: 63-74.

3. See genealogical table in Cooper r99г: I, r8I. 
was the eldest daughter of Alonso de Fonseca y Avellaneda (c. I44O-I5O5), II Lord of Coca, near Segovia, and Alaejos, near Toro, in what is now the province of Zamora. Her mother was María de Toledo, daughter of Fernán Álvarez de Toledo (d. I5O4), I Count of Oropesa, and Mayor Carrillo de Toledo, daughter of Fernando Álvarez de Toledo, I Count of Alba de Tormes. ${ }^{4}$ She had one sister Mayor de Fonseca (I49O/9I-I53I) and no brothers, which made it all the more important in the eyes of her father that she should marry a suitable husband, in other words a close relative- preferably a cousin- who would safeguard the family's inheritance.

María de Fonseca's great uncle Alonso de Fonseca y Acevedo (I4I8-I473), Bishop of Ávila and Archbishop of Seville, had obtained permission from Juan II of Castile to build castles at Coca and Alaejos on I5 July I 453 (Cooper I99I: I, I80), and in his first will, which he drew up when he was seriously ill in the house of Alonso Enríquez (c. I433-I485), III Admiral of Castile, in Valladolid on 3 September I46o, he had named his brother Fernando de Fonseca, who was a steward (maestresala) in the service of Juan II of Castile, as the heir to his estates (Franco Silva r999: 76; García OroPortela Silva 2002: 8I). This gentleman was María de Fonseca’s grandfather. It seems, however, that the archbishop did not give his brother permission to build the castle of Coca. The construction of this vast and impregnable castle, with its ornate red brickwork, did not begin officially until I488, long after the archbishop's death, under the supervision of the Moorish architect Maestre Farax, who was later replaced by Alí Caro (Vasallo Toranzo 20I4: 63 \& 7o). When the latter converted to Christianity, he adopted the name Alonso Fonseca from his patron, María de Fonseca’s father (Tapia Sánchez 2009).

Fernando de Fonseca died from a wound that he received from Beltrán de la Cueva on 20 August ${ }_{4} 467$ at the second Battle of Olmedo while fighting on behalf of Prince Alfonso, Queen Isabel's brother, against the troops of Enrique IV of Castile. ${ }^{5}$ On this same day, Pedro González de Mendoza (I428-I495), later Cardinal of Spain, the father of María de Fonseca’s future husband, was wounded in the arm fighting on the other side.

When, in September I467, Castile was torn apart by civil war, Enrique IV was forced by the league of rebellious nobles who had taken control of Segovia to entrust his flirtatious Portuguese wife, Queen Juana, to the care of the Archbishop of Seville, and she was kept as a hostage for two years in the fortress of Alaejos, guarded by the archbishop's brother-in-law Pedro de Castilla y Salazar (an illegitimate descendant of Pedro I of Castile), whose wife, Beatriz Fonseca, was one of her ladiesin-waiting. While Juana was in the castle of Alaejos she formed a liaison with her guard's son, Pedro de Castilla y Fonseca, and in August I468, when she was six months pregnant and could no longer conceal her pregnancy by the ingenious device of draping her dresses over wicker hoops, ${ }^{6}$ she managed to escape with the help of her lover, after being lowered down the castle wall in a basket tied to a rope of knotted sheets. She was conveyed on a mule first to Cuéllar to seek the assistance of her former lover Beltrán de la Cueva, and then to Buitrago, where her daughter Juana la Beltraneja lived under the charge of Íñigo López de Mendoza, I Count of Tendilla (I468), and where, on 30 November I468, she gave birth to twin boys. Today little remains of the castle of Alaejos because in

4. Some scholars say that María de Toledo was the daughter of the Count of Oropesa's second wife Leonor de Zúñiga (García de Carraffa r96r: 203). This, however, seems unlikely because in an investigation into the purity of lineage of her grandson Rodrigo Mexía when he sought admission to the Order of Santiago, dated 5 April I564, it is said that María de Toledo was a very close relative of the Duke of Alba (Rodríguez Martínez 20IO: 322 ).

5. Cooper (г99г: II, 994-95) suggests that the circumstances of Fernando de Fonseca's death seem to corroborate the theory that Beltrán de la Cueva was indeed the father of Juana La Beltraneja.

6. It is thought that this invention gave rise to the long-lasting fashion for the farthingale, or hooped petticoat (verdugado), which spread to France, Italy and England during the sixteenth century (Anderson I979: 208-209; Marino 2Оог: 49-50). 
I52I the comuneros vented their hatred of the Fonsecas by demolishing much of the building. ${ }^{7}$

Alonso de Fonseca had arranged that his daughter María should marry her cousin Pedro Ruiz de Fonseca (d. I5O7), the son of his half-brother Antonio de Fonseca y Ayala (d. I532) by his first wife Francisca de Alarcón. ${ }^{8}$ This plan had Queen Isabel's approval because it ensured that the castle of Coca would remain indirectly under her control. When María de Fonseca's father died in $5_{5} \mathrm{O} 5$ without male issue, her uncle Antonio de Fonseca assumed the title of Lord of Coca and Alaejos. This gentleman was extremely influential: he had saved King Fernando's life at the siege of Loja in I486; he was an Ambassador, with Juan de Albión, to the court of the Emperor Maximilian in I496; he was Princess Margaret of Austria's Majordomo in the years I497-I5OO; he was Chief Auditor of Castile in I5O3; he was a signatory of Queen Isabel's will; he was Captain General during the Comunero Uprising in I52O-I52I; and he was Comendador Mayor de Calatrava, and governor of the castles of Ronda, Plasencia, Jaén, Andújar and Pelagajar (Espejo de Hinojosa 193I).

But María de Fonseca was determined to marry Rodrigo Díaz de Vivar y Mendoza. In fact, as I shall explain in due course, she was already secretly married to him before she was forced to marry her first cousin. This highly cultivated gentleman, a grandson of the famous Marquis of Santillana, was Cardinal Mendoza’s eldest son by his mistress Mencía de Lemos (c. I437-I482), Lady of Villanueva y Gordaliza. This lady was the eldest daughter of Gomes Martines de Lemos, Lord of Trofa in Portugal, and María de Meira, Lady of Jalhés and Pampilhosa. She and her younger sister Margarita (d. I520) had entered Castile when Juana de Avis married Enrique IV of Castile in I455. Margarita was one of the court ladies who can be identified in Gonzalo Pinar's Juego trobado. ${ }^{9}$ Pedro de Cartagena (I456-I486) addressed several poems to her. In I 475 she married the Royal Steward Sancho de Rojas and acquired properties in Málaga after the surrender of that city in I487.

It has been widely assumed that Mencía de Lemos was a widow when she became Cardinal Mendoza's mistress, but actually she had a husband from whom she had become estranged. That husband was Diego de Quiñones y Tovar (I438-I404), Comendador de Estriana in the Order of Santiago and Lord of Villanueva de Valdejamuz, whose gallant motto Honor o fin, with the cross of St James, is still visible on the walls of his castle near León (Cooper I99I: I, 300; II, docs I4I, I63, I72). He was the son of Suero Pérez de Quiñones (I409-I458), and Leonor de Tovar, the same Suero de Quiñones who had challenged all chivalrous knights to joust with him at the famous Paso Honroso in July and August of the year I 434 at the bridge of the Hospital de Órbigo, near Astorga. Diego de Quiñones is the author of the canción 'En gran peligro me veo' (ID o78I, LBI-94) and an invención of a buckle in the shape of an unending loop, or love-knot (ID 6359, IICG-503), addressed, I believe, to the court lady Inés de Ávila, the eldest daughter of Gonzalo de Ávila (d. I482), Governor of Jerez de la Frontera, and his second wife María de Saavedra. Since a cancionero is listed among the few belongings that he left to his son (Alcedo I926: I66), it is likely that he is the author of other poems that are now lost. His first wife was Isabel Ordóñez, a lady of Salamanca (Cooper I99I: II, IO39).

Although Mencía de Lemos bore the Comendador de Estriana two children, the couple broke up not long after their wedding and she lived apart from him in Valladolid where for approximately twenty years she led a dissolute life: "vivió asaz pública y desonestamente, dando parte de su persona a muchos así parientes del dicho Diego de Quiñones como no parientes, habiendo acceso

7. Cooper (I99I, I, I82 nI2) notes that some repairs were done to the castle in I527, and he informs me that since 2013 it has been a site of archaeological excavation.

8. Antonio de Fonseca's second wife was Mencía de Ayala (Rodríguez Martínez 20IO: 312-I3), sister of Pedro López de Ayala, I Count of Salvatierra (I492), and daughter of García López de Ayala, Marshall of Castile, and María Sarmiento.

9. This will be discussed in my forthcoming book (Boase 20I7). 
de ellos carnalmente según es público y notorio" (Alcedo 1926: 93) (“she lived very publicly and disgracefully, sharing her person with many men, both relatives of the said Diego de Quiñones and non-relatives, having as is well known carnal intercourse with them'). She had three daughters, two of them by Juan de Reinoso, Lord of Castrillo. These details of Mencía's scandalous life are known to us as a result of a long and expensive lawsuit concerning the legitimacy of her marriage to Diego de Quiñones, initiated by the latter's malevolent cousin Diego Fernández de Quiñones (c. I42OI49I), I Count of Luna (I462), who seized his castle of Somiedo in Asturias in I480 and his castle of Villanueva de Valdejamuz in I485. In Valladolid, on I2 May I479, Mencía signed an affidavit that Diego de Quiñones, Commander of Estriana, was her husband, declaring that her previous denial had been motivated by fear. In Valladolid, on I2 July I482, she drew up her will. On I6 August I482, he likewise formally recognised that he had been her legal husband. His chief concern was to protect the interests of his son Diego de Quiñones y Lemos (d. I54O), whom the Count of Luna claimed was illegitimate and thus ineligible to claim the Quiñones inheritance of Villanueva de Valdejamuz. Diego de Quiñones II finally won the case on I4 July I528; it was then that the income that he should have received from Gordaliza since his father's death was reimbursed to him. ${ }^{\text {Io }}$

One of the witnesses at the trial, Diego de Gordón, attested that he had been working at Villanueva for ten or twelve years when the Comendador de Estriana announced his engagement to marry Mencía, whose fortune amounted to 400,000 maravedíes in annuities and income from the salt-works of Atienza near Sigüenza (Alcedo I926: Iog). His son Diego de Quiñones had been educated from the age of six by Nicolás Ortiz, Canon of Seville cathedral. This boy was barely ten years old when his father died (ibid. 40), which means that he must have been born c. I474. His place of birth was a hermitage on the road between Castromonte and Villanueva (ibid. II5). His stepbrother Rodrigo de Mendoza, the future Marquis of Zenete, whose disputed date of birth will be discussed later, was born at the Dominican hermitage of Santa María de Atocha, formerly outside the walls of Madrid (Falomir Faus-Marías 1994: IO2).

The Marquis of Zenete is a fascinating and complex person. He could be criticised for being impulsive, quick-tempered, vain, restless and ambitious, but it is generally agreed that he was urbane and learned with a fluent knowledge of Castilian, Catalan, Italian and Latin, and probably also some fluency in Portuguese and spoken Arabic; that he was keenly interested in music, poetry and books, ${ }^{\text {II }}$ and that he was an assiduous follower of the latest Italian fashions in art and architecture. Fernández de Oviedo clearly knew him well and greatly admired him, but unfortunately the seventeen folios devoted to him in his Batallas y quinquagenas are in such poor condition that they are almost illegible. His portrait of him is extremely, even excessively, flattering: he was wise, pious, handsome and magnanimous, combining the skills of a courtier, soldier, horseman and man of letters, although he admits that some people considered him mischievous (travieso) (Batallas Avalle: 396). In his opinion, those who knew him had failed to do him justice: “Todos los que vimos al marqués del Zenete, por muy bien informados que estemos de su persona y habilidades, y por mucho que sus buenas partes y linda disposición contemos, y por mucho papel y tinta que en sus loores se gaste, siempre avrá más que decir" ("All those who knew the Marquis of Zenete feel that, however well informed we are about his character and talents, and however much we may enumerate his good qualities and fine personality, and however much paper and ink is expended in his praise,

IO. Diego de Quiñones II married twice: his first wife was Isabel de Bazán; his second wife was Leonor de Zúñiga, whose son, Suero de Quiñones, was the last Lord of Valdejamuz.

II. By the time of his death he owned over 600 books, mainly by classical authors. Approximately 200 of these were sold in I529 and I535. Among his collection was a copy of the Cancionero general: in Valencia, on 3 April I529, it was sold to "Anthon Moreno" (Gómez-Ferrer 2OIOa: appendix no. IO2; cf. Sánchez Cantón I942). 
there will always be more to say'). ${ }^{12}$

As a young man Rodrigo de Mendoza must have had little time for studying because, from the siege of Baza in I489 until the surrender of Granada in January I492, he was engaged in warfare, although admittedly the Latin teacher Pietro Martire d'Anghiera (I457-I526) was one of his companions in arms. At the siege of Baza he and his uncle Pedro Hurtado de Mendoza, Adelantado de Cazorla, each led a regiment of five hundred of his father's cavalry. Although Rodrigo was a young man with no military experience, he bravely defied the onslaught of the Moorish crossbows and muskets to recover the flag when he saw that the ensign-bearer, Juan de Perea, had been struck in the arm by a cannonball, and he had the presence of mind to urge his men to remain calm (Carriazo ed. 1943: 377).

On 7 May I489 the Catholic Monarchs awarded him the post of Chancellor of the Secret Seal (canciller del sello de la Poridad). In I49I they granted him the title of Marquis of Zenete and in I492 that of Count of El Cid. On I5 June I 476 Queen Isabel signed a certificate legitimising Cardinal Mendoza's offspring. Two years later Pope Sixtus IV gave him authority to bequeath to them his possessions, but without clearly recognising their legitimacy. In Córdoba, on 3 May I487, Queen Isabel again issued a certificate legitimising Rodrigo and his brother Diego. After obtaining a papal brief from Innocent VIII, Cardinal Mendoza, on 24 August I488, granted to Rodrigo the right as his first-born to inherit his lands in Guadalajara (Marías I990: I2I). At Úbeda, on 3 November I489, the Catholic Monarchs had legitimised Rodrigo's birth and his right to inherit the fortress of El Cid and Jadraque near Guadalajara. ${ }^{13}$ Alberic, Alcosser and Alasquer, in the Kingdom of Valencia, and Guadix and Zenete, near Granada, were added to the mayorazgo in I49O and I49I. Then at Cogolludo near Guadalajara, on I May I493, in the presence of the king and queen, he married his cousin Leonor de la Cerda (I472-I 497), the only daughter of Luis de la Cerda y Mendoza, I Duke of Medinaceli, and his second wife Ana de Navarra y Aragón (I45-I-I776), daughter of Carlos (I42I-I46I), Prince of Viana, King Fernando's half-brother and the rightful heir to the Kingdom of Navarre.

Leonor de la Cerda had originally been promised in marriage to Jorge Manrique de Lara, the eldest son of Pedro Manrique, Duke of Nájera, and Guiomar de Castro, by a pact that the two dukes had made in I49I. This pact was broken by the marriage contract signed by the Marquis of Zenete in Zaragoza on 2 October I492. Then, on 27 March I493, during festivities in Barcelona organised for the Catholic Monarchs, and much to the consternation of the court, Manrique de Lara, who was barely thirty years of age, had died suddenly after a high fever. ${ }^{\mathrm{I}} \mathrm{But}$ the marriage between the marquis and Leonor de la Cerda was all too brief because, four years later, on 8 April I 497, she died in childbirth in the castle of Jadraque. ${ }^{15}$ Had the child lived, the marquis would have inherited I2 million maravedíes from his father-in-law the Duke of Medinaceli (Zalama I99I: 2I).

After the death of his first wife, the Marquis of Zenete, now a wealthy widower with few domestic

I2. Batallas y quinquagenas, Biblioteca Universitaria de Salamanca, ms. 359, ff. 810-8II ${ }^{\mathrm{r}}$, cited in Falomir FausMarías I994: IO2.

I3. Biblioteca Nacional, Sección de manuscritos, S-39, cited in Catalina García i899: 679 n4. It was then also that his brothers Diego and Juan were legitimised.

I4. To relieve his thirst after a game of piedra gruesa in the streets of Barcelona, he drank a jug of cold water and soon afterwards died, after contracting a high fever (Batallas Avalle: 346), perhaps a symptom of typhoid. This seems to be the same as the game of "pelota gruesa", mentioned in a document in the Segovia archive, dated 5 February I573 (Ruiz Hernando I982: 318). It involved hitting a stone against a wall. Juan de Leyva, a knight in the service of the Duke of Nájera, wrote a ballad to commemorate this event (Avalle-Arce I992).

I5. This castle, dominating the valley of the River Henares, had been entirely rebuilt by her father-in-law Cardinal Mendoza, who died in Guadalajara on II January I 495. 
responsibilities, made several trips to Italy. By the end of August I 499 he was in Naples, whence he travelled to Rome. He spent Christmas in Milan, which was then occupied by the French troops of Louis XII, and where he met the papal legate Juan de Borja Llanzol, Archbishop of Valencia, Pope Alexander VI's nephew, and the chronicler Gonzalo Fernández de Oviedo, who had entered the city with the French king and Cesare Borgia on 6 October I499. On New Year's Day I5Oo, the marquis arranged for five cartloads of artefacts to be transported to Genoa and shipped to the port of Cartagena, and by the end of September he was back in Valencia. In I5OI, after spending four or five months at Jadraque, he travelled to Andalusia, returning at the end of the year to spend Christmas in Valencia (Falomir Faus-Marías I994). By then it seems that he had definitely decided that, despite royal opposition, he would marry María de Fonseca, although it is not known where the two first met.

Accompanied by two squires, García de Montalvo, a native of Medina del Campo ${ }^{16}$ and Luis Enríquez, his servant Juan de Albornoz, and his groom Barreda, the marquis travelled from Olmedo to Santa María de Nieva near Coca. He arrived there on 29 June I502, the day of St Peter, and saw María de Fonseca and her mother in the church and dined with them afterwards in the town. That evening, after leaving his horses at a nearby hermitage in the care of his groom, the marquis, with his three companions, entered the Coca estate through an orchard, and at one o'clock in the morning he secretly married María, with her mother's connivance, in a gallery of the castle. Two maidservants of the Fonseca family, Teresa del Castillo and Beatriz Gutiérrez, who were later severely punished, witnessed the brief ceremony, and two copies of the marriage certificate were signed. It was agreed to keep the marriage secret until the marquis had obtained the queen's approval. After spending the night with his new bride, he departed at daybreak. ${ }^{17}$

It was not until $\mathrm{I}_{5} \mathrm{O} 4$ that María's father discovered what had happened, and he was so furious that he locked up both his wife and daughter in the castle of Alaejos. There he stripped his daughter naked and whipped her with a knotted cord until she bled. María wrote letters to Queen Isabel and to Cardinal Cisneros appealing for their help, but the queen paid no heed. She gave the Lord of Coca permission to marry his daughter to his nephew Pedro Ruiz de Fonseca, who was then still a minor, less than fifteen years old, and she issued a decree at Alcalá de Henares, on I5 May I5O3, permitting a father to disinherit any daughter who married without having obtained his consent. This decree, later known as 'la ley de Toro', was finally ratified after the queen's death on II January I5O5 at the Cortes de Toro.

The Lord of Coca's cruel treatment of his wife and his eldest daughter and the scandal caused by the Marquis of Zenete when he finally abducted his bride from the convent of Las Huelgas must have provoked a heated debate at court about a woman's right to marry the husband of her choice, and it is interesting to discover, from the evidence of a poem addressed to the marquis, that the humanist

I6. This gentleman may be identified as García de Montalvo el mozo, a nephew of García Rodríguez de Montalvo, who reworked the story of Amadís and composed Las sergas de Esplandián, hïo de Amadís (Seville, July I5IO), a chivalric romance reflecting the situation of Spain in the years s 495-97. The younger García de Montalvo was already, like his uncle, an alderman (regidor) of Medina del Campo in I5OO. He is depicted as a knight in full armour in a painting of the Descent from the Cross by Pedro Machuca, completed in $5_{547}$ (Museo Nacional del Prado Po3or7), commissioned by his wife Inés del Castillo. He was involved in the Comunero revolt (I52O-22) and was in Venezuela c. I54O (Sales Dasí I999: І29-34).

I7. Details of these events, recorded in connection with the case brought before the ecclesiastical judge in Valladolid in ${ }_{5} 55$ over who was María de Fonseca’s rightful husband, were resurrected in 5593 in a lawsuit over the inheritance of Alaejos and Coca between Íñigo López de Mendoza y Fonseca, Marquis of Zenete and Duke of El Infantado, and Rodrigo Mejía y Fonseca, Marquis of La Guardia (Archivo Histórico Nacional, Sección Nobleza, Osuna, Leg. 2225 , no. IO). Córdoba de la Llave (2OII) bases his research on these documents. 
Lucio Marineo Siculo (c. I444-I536), ${ }^{18}$ a native of Sicily, who by I 497 was a Latin teacher at the royal court, adopted a point of view totally at variance with that of the queen (Carmen 2O, in Verrua I9o6: 4I):

Quis prohibere valet natam, quae flagrat amore Legitimo? poscitque dare sibi nuptae maritum? Non probo vos placido vestram privare puellam Coniugio, pactoque viro, thalamoque petito. Nam pater electum si non concedat amantem, Nata patrem matremque suam cunctosque propinquos Odit, et optatum foelix amplexa maritum Gaudet, et ipsorum vivit secura parentum. Immemor ipsa sui est, sponsum quae diligit uxor, Cuius in amplexu fervens et amoribus haeret Tota, nec occurrens pater illi gaudia rumpit. Hoc olim multae, nostro sed tempore plures Hoc faciunt natae, quibus est non equa voluntas Patris: at illarum iustis contraria votis Lex dedit hoc ipsis; dedit hoc natura puellis, Quaecunque ignitis stimulis agitantur amoris.

(Who is able to forbid a daughter when she burns with a legitimate love and begs to be allowed to take a man to herself in matrimony? I do not recommend depriving your daughter of a peaceful marriage and the wedlock that she longs for with a man who has plighted his troth to her. For if a father does not accept her chosen lover, the daughter hates her father and mother and all her relatives, and she rejoices in the happy embrace of her chosen husband and lives unconcerned about her own parents. Disregarding her duty of obedience, the wife selects her suitor, cleaves utterly to his love and ardent embrace, and then her father does not oppose her and destroy her bliss. This is what many girls in the past did, and many more do today: this is caused by a law that conflicts with a daughter's lawful wishes and by nature when any girls are stirred by the incitement of love's fire. $)^{19}$

In Christian canon law, as in Roman law, mutual consent and sexual consummation have always been considered the twin pillars of marriage, and before the Council of Trent (I563), provided that there were witnesses, secrecy was not in itself regarded as an obstacle. Indeed, according to Erasmus, "the Church declared clandestine marriages valid in order to put an end to the tyranny exercised by parents". ${ }^{\circ 0}$ Non-consummation was generally regarded as an impediment to marriage and was frequently used as a ground for annulment, but consent was considered by the Church to be the essential minimum. This was the position that the Church had adopted since the thirteenth century. Even in the case of marriages of convenience, when children of noble birth were betrothed and married at a very young age, the consent by the partners themselves was considered vital (Brooke I989: ı29; Beceiro Pita - Córdoba de la Llave ı990: I28-3I). In Las siete partidas, the lawbook commissioned by Alfonso $\mathrm{X}$ of Castile, it is stated that consent alone is what makes a marriage valid: “consentimiento sólo, con voluntad de casar, faze matrimonio entre el varón y la muger" (IV, tit. 2, ley 5). An Aragonese chronicler makes this point in his discussion of the events preceding the marriage of Isabel and Fernando:

I8. For new information about his life, including his dates of birth and death, see Ramos Santana 2000.

I9. I am very grateful to Kathryn Hamilton and Frank Newsum for assisting me in translating this text.

2O. He expressed this view in Christiani Matrimonii Institutio, a work written at the request of Catherine of Aragon in I526 (Joyce I948: I2I), but he did not think that such a marriage deserved to be accorded the status of a sacrament. 
It happened that the princess, who was alone and deprived of her lawful and rightful liberty and freewill- which after God's grace is what is chiefly required in the business of marriage- secretly made known to the grandees, prelates and knights, all subjects of the king her brother and countrymen, the methods used to persuade and compel her, asking them for their opinion and advice. ${ }^{21}$

One would have thought that Queen Isabel, who was fully aware of her rights and who had herself flouted the wishes of her half-brother Enrique IV of Castile in order to marry in secret the husband of her choice, ought to have been more sympathetic to María de Fonseca's situation. She had made it clear to the Portuguese delegation in Ocaña, in the winter of I468, that she would never consent to marry her cousin King Afonso of Portugal: according to Pedro d'Escavias (Sitges 1912: 404), "a la Princesa non placía dello"; or, in the words of Diego Enríquez del Castillo (Sánchez Martín ed. 1994: 318), "en ninguna manera no lo entendía hazer, ni consentir en ello". ${ }^{22}$ Poets at the royal court during this period were so aware of this notion of consent that it became the central unifying theme of a cycle of poems in the British Library Cancionero (LBI), all associated with the King of Portugal's courtship of the young princess (Boase 2006).

The Marquis of Zenete's secret marriage was celebrated in a ballad composed by his friend Quirós, with the rubric Romançe hecho por Quirós sobre los amores del Marqués de Zenete con la Señora Fonseca (ID 6349, IICG-476). This first-person narrative, by a lover who travels through a visionary Dantesque landscape, is a semi-allegorical account of what actually happened. After crossing a desert, the narrator comes to a village with a dry spring, una fuente seca (Fonseca): like Tantalus, he finds that the greater his thirst, the dryer the spring becomes. When his care slumbers, the water flows, sweet to look at, but impossible to drink, and when he awakes at dawn, he is filled with grief because the spring is dryer than ever: "Y después que fuy despierto / mayores males sentía, / que hallé la fuente seca, / más seca que no solía” (lines 53-56). It was perhaps on this occasion that the marquis, betrayed by a nameless person, was nearly burnt alive in a cellar of the castle. ${ }^{23}$

Quirós can now be identified as Gonzalo de Quirós, who became well acquainted with Rodrigo de Mendoza in I489 when, for nearly five months, between August and December, they laid siege to Baza. Quirós was promised a gift of 300 ,ooo maravedíes for his valuable service to the Crown in the conquest of Baza, and it was almost certainly as a penalty for his association with the future Marquis of Zenete that he never received this reward in full until $\mathrm{I} 5 \mathrm{I} 9$, and even then only after a lengthy lawsuit (Andreoli 2005: I-7; Prieto Cantero I969: 400, 479, 522). By I525 his property in the region of Baza included four houses, three ovens or bakeries, one bath-house, two vineyards and 900 orchards (Tristán García 2007: 595-96).

Quirós also composed a gloss of the Marquis of Zenete's paradoxical mote 'Quien no te precia t'aprecia' (ID 6748, IICG-624) ('He who does not place a price on you appreciates you'). He reasons

2I. "De allí se siguió que la princesa como sola y enajenada de la justa y debida libertad y de su franco albedrío, que en negocio de matrimonio después de la gracia de Dios principalmente se requiere, hizo secretamente saber a los grandes, perlados y caballeros súbditos del rey su hermano y sus naturales las formas que se tenían para inducirla y apremiarla, demandándoles su parecer y consejo”, according to Jerónimo Zurita (Canellas ed. I988: VII, 6I2).

22. She had sworn to the king that she would marry in accordance with his command, provided it was not against her will: "La prinçesa juró de obedeçer, seguir y servir al rey, y de se casar por su consejo y mandamiento, tanto que con quien la él casase fuese por grado y voluntad della mesma y non forçada nin constreñida para ello deste rey” (Puyol ed г934: 67).

23. Fernández de Oviedo writes: “por parte de los Fonsecas faltó poco para quemarle bivo en la cava o fosos dela fortaleza de villa de Coca por yndustria de un traydor como mejor sabéys” (Falomir Faus-Marías i994: Io3; Batallas Avalle: 396 ). The manuscript is in too poor a condition to obtain any further information about this incident. 
that "since the lady was born sin precio (priceless), then the man who does not prize her, or is unable to put a value on her charms, esteems and appreciates her" (Macpherson 2004: 83). In other words, it is impossible to praise the lady sufficiently because her merit cannot be quantified. Whether this poem was addressed to María de Fonseca is uncertain. It would certainly seem that in his second marriage the marquis was motivated more by love than by the pursuit of wealth because, although he never relinquished his claim to be the rightful Lord of Coca, he knew that, without the queen's approval of his marriage, he had no chance of making good his claim.

On 8 April I504, Queen Isabel imprisoned the Marquis of Zenete in the castle of Cabezón de Pisuerga, near Valladolid, and later transferred him to Simancas, accusing him of having led a scandalous life in Valencia at the court of Joanna (I479-I5I8), King Fernando's niece and the widowed queen of Ferrandino II of Naples (I469-I496). The queen attempted to persuade María to comply with her father's wishes, but she stood firm: she sent a letter to the queen, informing her that the marquis was not merely her spouse, mi esposo, but also her husband, mi marido (García I899: 680). A marriage contract between María and her young cousin was drawn up in December I5O3. Then, while awaiting the arrival of a papal dispensation from Pope Julius II permitting her to marry her cousin - which was eventually dispatched on 22 February I5O4- María’s father was shocked to learn at Easter that his daughter's secret marriage had been consummated. Undeterred, he tricked her into believing that her first husband had been executed, and on the night of $2 \mathrm{O}$ June I5O4 she was forced to marry her cousin in the castle of Alaejos in the presence of the whole family, including her uncle Juan Rodríguez de Fonseca (I45 I-I524), Bishop of Córdoba and subsequently Bishop of Burgos, and on the following day a cleric named Bachiller Ochoa Arias blessed the couple (Córdoba de la Llave 20II: 334-35). This second marriage, however, was never consummated: having discovered that she had been deceived and that her first husband was still alive, she warned Pedro Ruiz on the wedding night- in the words of Catalina de Castilla, who was one of the witnesses at the court proceedings in I5O6- that she would twist his neck like a chicken if he dared to approach her (Ibid. 2OII, 343). Juan Velázquez, another of the witnesses, said that at two o'clock at night the girl's farther had demanded to see her nightshirt and could find no blood on it. She again wrote to Cardinal Cisneros, urging him to intercede. Queen Isabel's health had meanwhile declined: she died on 26 November I504. María's father died in August of the following year, and some people said that his anger had contributed to his early death (Batallas Avalle: 59). In his will he had stipulated that María should be disinherited if she did not remain married to her cousin Pedro Ruiz, and if this marriage ended, his other daughter Mayor should marry him instead.

On 22 November I5O4, a few days before the queen's death, the Marquis of Zenete was released. Soon afterwards, in order to obtain papal approval of his marriage, he made another trip to Italy, remaining there for more than a year. He had meanwhile written to Juan Ruiz de Medina, Bishop of Segovia, on 4 November I5O4, urging him to declare María as his legitimate wife, and he had initiated legal proceedings in Valladolid, challenging the validity of María's marriage to Pedro Ruiz. María herself wrote to the Bishop of Segovia on 2I January I5O5, begging him to get her released from the castle of Zamora where her uncle Antonio de Fonseca had locked her up, pleading on behalf of her mother who was then a prisoner in the castle of Alaejos, and complaining that her sister Mayor de Fonseca and other women had mistreated her (Córdoba de la Llave 2OII: 33I-39). King Fernando, who now acted in Castile as regent while awaiting the arrival of Juana's husband, Philip the Fair, Archduke of Austria, ordered the lady to be moved from Zamora to the castle of Arévalo under the care of Juan Velázquez de Cuéllar (d. I5I7) and his wife María de Velasco while the case was pending. From a letter that King Fernando sent from Valladolid to Rome, addressed to his ambassador Francisco de Rojas, dated 24 April I5o6, we know that María de Fonseca was transferred to the security of the royal convent of Las Huelgas in Burgos for fear that there would 
be a scandal if one of the parties claiming to be her husband managed to carry her away by force. He asked the ambassador to obtain a papal brief granting him permission to hold her in the convent where she would be free to consult with her lawyers while the ecclesiastical judge decided who had the best claim to call himself her legal husband (Rodriguez Villa rog6: 446).

By the end of April I5o6 the marquis was already in Valladolid, although it was not until I7 September that he was officially authorised by Philip the Fair to return to the city, and then only on condition that he did not seek to make contact with María. Only a week later, on 25 September I506, Philip suddenly died, and taking advantage of the confused state of affairs following this event, the marquis was able to elope with his bride when she escaped from the convent of Las Huelgas by climbing out of a window. He first took his new wife to the castle of Jadraque, where they remained until the end of March $5_{508}$, and where a friar blessed their marriage. Then the couple moved south to Alcudía de Guadix, north of Granada in the marquisate of Zenete. His cousin Iñigo López de Mendoza (I442-I5I5), II Count of Tendilla, invited him to stay in the Alhambra Palace where the count was Governor, but it is uncertain whether he was able to accept this offer of hospitality because during this period King Fernando banished the marquis from Granada, fearing that his presence in the city would spark off a popular uprising. In later years, for political reasons, relations between the two cousins inevitably became strained. In a letter, dated I2 July I509, the Count of Tendilla reports that the marquis had once complained to his wife that he, the count, and Cardinal Cisneros had fallen out with him because they expected him to be prudent like them: "Creo que piensan que tengo yo de ser cuerdo como ellos" (Meneses García 1973-74: I, 642).

Channelling his energies into architecture, the marquis now set about completing the palace of La Calahorra, near Guadix, on the edge of the Sierra Nevada, which his father had started building in I49I (Ruiz Pérez 20I4: I70-76). The Count of Tendilla estimated that the marquis spent more than I80,ooo gold ducats on this construction work (Gómez-Moreno I925: 37). To the austere military exterior of the house built by Lorenzo Vázquez de Segovia- the architect commissioned by his father to design the façade of the Colegio Mayor de la Santa Cruz in Valladolid- the marquis now added a delicate Renaissance interior, with a staircase of Carrara marble, a courtyard by the Genoese architect Michele Carlone, and many other features imported from Italy. It was perhaps this radical change of plan, as well as the harsh working conditions, that resulted in a violent dispute between the marquis and Lorenzo Vázquez when the Count of Tendilla had to intervene by sending the architect's son with a letter, dated I3 June I509, ordering the architect's release from imprisonment. The marquis was impatient to realise his architectural dreams, and the Count of Tendilla's letters reveal how much the marquis was feared by his Moorish labourers and artisans because he wielded a stick and made them work long hours. For example, Francesco el Valencí, an expert in constructing water-cisterns, fled to Granada and had to be compelled to return (Gómez-Moreno r925: 33-34).

In I5IO, while the construction work continued at La Calahorra, the marquis moved to Valencia where he had been appointed Governor, and transferred his energies into redesigning his house and gardens at Alcosser near Alberic (Gómez-Ferrer 2OIob). He and his family returned to Granada in the autumn of I5I2 and stayed with Gonzalo Fernández de Córdoba, el Gran Capitán. They were finally able to move into their new palace of La Calahorra on ${ }_{1}$ February ${ }_{15}{ }^{\mathrm{I}} 3$, but they never lived there for long because his support for a rebellion led by Pedro de Girón, son of the Count of Urueña, caused him to be again banished from Granada on I4 March of that year. He then decided to return to Valencia. It was in Ayora, near Almansa, on 9 September I5I4, after twelve years of marriage, that the marquis and his wife finally drew up a formal wedding document.

María de Fonseca died in Valencia on Friday i6 August I52I and was buried a week later in the Monastery of the Santíssima Trinitat, where three days later friars from all the four mendicant orders prayed for her soul, according to Martí de Viciana (Iborra ed. 2005: 424). After her 
death the marquis became deeply involved in the task of resolving the revolt of the Germanies ('Brotherhoods'). After failing to negotiate with the more moderate of these republican revolutionaries, he was seized by a group of radicals led by Vicent Peris and was held as a hostage in the castle of Xàtiva from 28 January to 9 February ${ }_{5222}$. He was only released when his brother Diego Hurtado de Mendoza, the Viceroy of Valencia, guaranteed that those responsible for his incarceration would be well treated. When Peris returned to Valencia with only thirty companions on the night of I8 February I522 in a desperate attempt to provoke an uprising, the marquis sought in vain to arrange an amnesty. In the end Peris and fifteen of his companions, including two women, were executed (García Cárcel r981: ı28-29).

A year later, on the 22 February ${ }_{5} 5^{23}$, the marquis died of fever in Valencia, without having prepared a will, and was buried a week later beside his wife. ${ }^{24}$ News of his approaching death attracted a crowd of creditors. A list was drawn up of 44 artisans, some of them well-known revolutionaries (agermanats), who had lent the marquis more than I,349 Valencian pounds -debts that were not finally settled until nearly four years later, according to Viciana (Iborra ed. 2005: $54^{2}$ n845). In I536 Mencía de Mendoza obtained permission from the Emperor Charles V to be buried in the Capella dels Reis, in the Convent de Sant Domingo, in what is now the Capitanía General de Valencia, and to have the corpses of her parents, the Marquis of Zenete and María de Fonseca, reinterred there, and she gave instructions for the chapel to be restored. The splendid sarcophagus where the marquis and his wife lie buried is made of white Paros marble, sculpted in Genoa by Giovanni Carlone and Giovanni Orsolino, commissioned by Lluís de Requesens and completed in I565 (García Pérez 2007-2008).

Although the Marquis of Zenete does not figure as a poet in the list of contents of the I5II edition of the Cancionero general, the anthology contains two works by him: a jousting device (invención) and a motto (mote). The invención depicts a treble string of a lute, una prima de vihuela, the most slender string, with the letra Nula segunda (ID 4I53, IICG-567). Since his first wife, Leonor de la Cerda, was also his cousin (prima), this invención must have been composed for her or in her honour. Either it was displayed at the Barcelona tournament in the spring of I 493 where he received a prize for his gallantry, "el precio de más gentil hombre", ${ }^{25}$ which was an award to the jouster with the most splendid attire and the most ingenuous invención, or it was displayed at the jousts that took place in Zaragoza in the summer of $\mathbf{4} 498$. This first tournament took place immediately before his marriage in Medinaceli on I May I 493, and the second occurred after the death of his first wife. The earlier date is much more plausible.

The idea of making a pun on the word prima seems to have come from a canción by Gonzalo Mexía, VI Lord of Santa Eufemia, the grandfather of Rodrigo Mexía, Lord of La Guardia, near Jaén, and VIII Lord of Santa Eufemia, the wealthy gentleman who soon after I5O5 married María de Fonseca's sister Mayor de Fonseca. ${ }^{26}$ Gonzalo Mexía had obtained a papal dispensation to marry

24. Viciana (I566, IV, ff. 218v-2I9 Catalina (I899: 68I ni6) and García de Paz (2008) give the date as 8 March. Yet, according to another source, he was killed by a stone thrown from a flat roof while attempting to pacify a rebellious mob (Boix I867: 7I).

25. The prize for the best jouster was given to Diego de Castilla, Lord of Herrera de Valdecañas (Batallas RAH II, 358). The division of prizes at jousts is more clearly explained in novels of chivalry such as Don Florindo (Río Nogueras I994: 3II).

26. Garci Sánchez de Badajoz mentions Rodrigo Mexía, Mayor de Fonseca’s father-in-law, in his Infierno de amadores (st. 40), but it would seem that this gentleman was not a poet, which is why the canción allotted to him is by Hernán Mexía (ID o686, IICG-II9). On ıo February ı487 Rodrigo Mexía married María Ponce de León, daughter of Rodrigo Ponce de León, Duke of Cádiz. Their son Rodrigo Mexía, VIII Lord of Santa Eufemia, was a staunch royalist, who in the years $5_{520}$-I $5^{2 I}$ suppressed the revolt of the comuneros in Jaén and Badajoz. 
his first cousin Inés de Guzmán, ${ }^{27}$ the daughter and heiress of Rodrigo Mexía y Carrillo, Lord of La Guardia (Batallas RAH: II, 4O \& 55). In Mexía's canción, 'Mucho me duele mi pena' (ID 6242, IICG-344), the prima, 'prime', refers to the first hour of prayer at dawn, and to the poet's wife and cousin, who had recently died: "no he visto un ora buena / después que passó la prima" ('I have not had a good time / since the passing of the first hour of the day, or since the death of my cousin'). This same pun on prima, meaning either a female cousin or a treble string, occurs in a poem by Jorge Manrique, in which the poet complains about a cousin, una prima falsa, whose interference in his amorous affairs is compared to a false top string that disrupts the tuning of an instrument (Morrás 2003: 177).

On the evidence of a passage by Fernández de Oviedo, the Marquis of Zenete designed this invención for Prince Juan at least a year before the death of Leonor de la Cerda because the words NULA SECUNDA were inscribed on a harp that he gave to the prince when the boy was receiving music lessons from an Italian teacher:

I remember the time when he [Prince Juan] was a youth at court and had a musician named Ludovico of Ferrara who played the harp exceptionally well, and the marquis made him play on a large and very beautiful harp, on which were painted at intervals some skeins of thin strings, each one like those that are inserted in the lute and are called prima. Around them were some inscriptions with capital letters, with the words NULA SECUNDA. ${ }^{28}$

The marquis must have given the prince this present before the end of April I 496 when the prince left the royal court to set up his own household at Almazán. This letra was highly appropriate because Prince Juan was in love with his cousin Marina de Aragón (I478-I5II), the future Princess of Salerno, daughter of his father's half-brother Alonso de Aragón, I Duke of Villahermosa, and the court lady Leonor de Soto. ${ }^{29}$ As Prince Juan was then engaged to marry Margaret of Austria, and had been since 20 January I 495 , the queen, if she understood the message, would obviously not have been amused.

During the last years of his life, when the marquis was living in Valencia, he devised another letra or mote, Laudo mia sorte ('I praise my fortune'), which was also inscribed on a musical instrument, and in fact occurs in at least five different places. First of all, we know from a letter dated I3 July I522, nearly eleven months after the death of his second wife, that the marquis ordered a mason, Joan Baptista Corbera, to inscribe these words around the window of Batiste Burguerino (Bautista Burguerini), a converso merchant and money-lender, a native of Sienna living in Valencia. ${ }^{30}$ Secondly, this mote occurs in gold letters on a claviorganum (claviórgano), one of many stringed instruments in the Marquis of Zenete's collection, a combination of a harpsichord and an organ..$^{3 \mathrm{r}}$

27. It was for her that Fray Ambrosio Montesino composed a romance c. I485 on the life of Mary Magdalene, which is found in two versions (Rodríguez Puértolas ed. r987: г96-20I).

28. "Bien me acuerdo que el tiempo que era mancebo en la corte thenía un músico llamado Ludovico Ferraries que tañía una harpa excellentemente, y el marqués le hizo hazer una harpa grande y muy hermosa, pintadas en ella a trechos unas madexas de cuerdas delgadas, cada una como aquellas que ponen en la vihuela y se dizen prima. En torno, unos

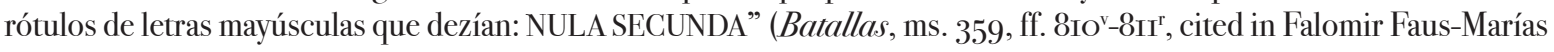
I994: IO3).

29. I discuss this in my forthcoming book on Pinar's Juego trobado (Boase 2OI7).

30. Archivo Histórico Nacional, sección Osuna, C. 1934, D. I3: "A Mosén Batista Corbera cantero seis ducados quel marqués le mandó dar porque fizo las letras de Laudo mia sorte en la ventana de Batiste Burguerino, I3 de Julio de I522” (Gómez-Ferrer 2oiob: 43 ni6).

3I. This instrument was covered in black velvet, the interior lined with crimson brocade: "hun instrument ques diu claviorgano cubert de vellut negre e lo ques mostra a la part de dins forrat de brocat carmesi d'esglesia ab la clavaso 
Thirdly, it was drawn by the painter Paolo de San Leocadio (I447-C. I522), an Italian painter who had settled in Valencia, on a carpet depicting the story of Laodamia (Gómez-Ferrer - Samper 1995), the virtuous widow of Protesilaus, a prince of Thessaly, who committed suicide when her husband was killed by Hector outside the walls of Troy, as recounted by Lluís Vives in his De institutione feminae christianae (Fantazzi-Matheeussen ed. 1998: II, 24).

Finally, the mote occurs twice in the works of the poet and lutanist Luis de Milán. It is mote 73 in his Libro de motes de damas y caballeros, published in Valencia by Francisco Díaz Romano in I535 (Vega Vázquez 20o6: 26I):

$\begin{array}{ll}\text { [dama] } & \begin{array}{l}\text { La dama qu'e[n] su mote está, } \\ \text { si la veis en esta sala } \\ \text { dezilde, con mucha gala: } \\ \text { 'Laudo mía, Laudomia'. }\end{array} \\ \text { [caballero] } & \begin{array}{l}\text { Laudomia es } \\ \text { la q[ue] siempre fue, después } \\ \text { y antes d'ella, } \\ \text { de su nombre la más bella. }\end{array}\end{array}$

As the lady who plays the game says, her name is contained in her mote: Laudo mia sorte.

This lady can be identified as Laudomia Burguerino, daughter of the Italian merchant Bautista Burguerini and Catalina López de Perona, daughter of a Valencian apothecary. Her mother's younger sister, Isabel López, or Isabel Llopis, became the third wife of the painter Paolo de San Leocadio (Mérimée I9O7: xxiii), which would explain why this painter was so familiar with the Marquis of Zenete's mote. The painter's marriage was arranged by the girl's brother, Jaume Llopis, a Valencian banker, in September I 493 (Aliaga et al. 20I4: 334). Laudomia married Galceran Carròs, Lord of Cirat, Pandiel, Tormo and Toga, who, as one of the leading noblemen of Valencia, was called upon to play a role in the suppression of the Germanies (Esquero 200I: 206)..$^{2}$

Laudomia is mentioned again in a game devised by Luis de Milán in El cortesano (Escartí-Tordera ed. 200I: I, 595):

Toma, bivo: te lo dó.

A doña Laudomia hirás, que un galán dixo por ella:

'Ésta es, cierto, la más bella

qu’en mi gala vi jamás.

Esta remontó mi corte,

por ella sé qu'es amor.

Laudo mía, forte amor,

laudo mia sorte’.

According to Fernández de Oviedo, the emblem on the Marquis of Zenete's helm was a garland, wreath, or festoon (festón), a symbol of love, connected with the moon and the tides, and with the goddess Venus, with the letra: "Aquestos secretos tales / son conformes a mis males" ("These secrets are such / as are in accordance with my woes'). Only fragments of his commentary on these

daurada ab letres que diu en Laudo mia sorte" (AVM, L.M. 327, Gómez-Ferrer 2OIob: 45 n5I).

32. Her granddaughter Laudomia Carròs, who married Gaspar Mercader y Moncada, Lord of Buñol, was the mother of the Valencian poet Gaspar Mercader (I568-I63I). 
words are now legible (Batallas Avalle: 397):

... sumergida en unas partes e cresçe en otras, con que [...] causa a los ombres [...] e dessa misma manera [...] sin un puncto ser parado ni çesar porque [...] secreto o callado como nos paresçe Marquesa doña María no fueron menos ocultos que esotro secreto de la mar ...

There seems to be a reference here to the sea as an image of love and fortune, and to the mysterious rise and fall of the tides that are linked to the waxing and waning of the moon, to women's menstrual cycles, and to the lover's changing moods. The word festón also means a 'scallop', the shell that symbolises Venus, as exemplified in Botticelli's Birth of Venus, and puncto suggests punto de festón, a type of stitch known in English as scallop trimming. The secreto de la mar, the secret of the sea, is the secreto del amar, the secret of loving. The word festón contains the first five letters of the name Fonseca; while the words María and Marquesa are associated with mar, sea, and marea, tide. Sereno, the narrator’s friend in Fernández de Oviedo’s Batallas y quinquagenas, then explains that the Marquis of Zenete's greatest source of disappointment was his failure to produce a surviving male heir. It is thus likely that he envied Galcerán Carròs and Laudomia Burguerino who had six sons and two daughters: if the mote Laudo mio sorte is spoken by her, this is the good fortune to which she surely refers.

The marquis and his wife María de Fonseca had a son, Rodrigo, born in August I5Io, but he died at the age of three, and they had three daughters. The eldest, Mencía de Mendoza, born on I December I5o8, was a beautiful, forceful and cultured lady. After her father's death, Mencía inherited his titles as Marchioness of Zenete and Countess of El Cid. In I524 the Emperor Charles V married her in Burgos, with much feasting and jousting, to his High Chamberlain, Henry, Count of Nassau-Dillenburg, Viscount of Antwerp and Lord of Breda.

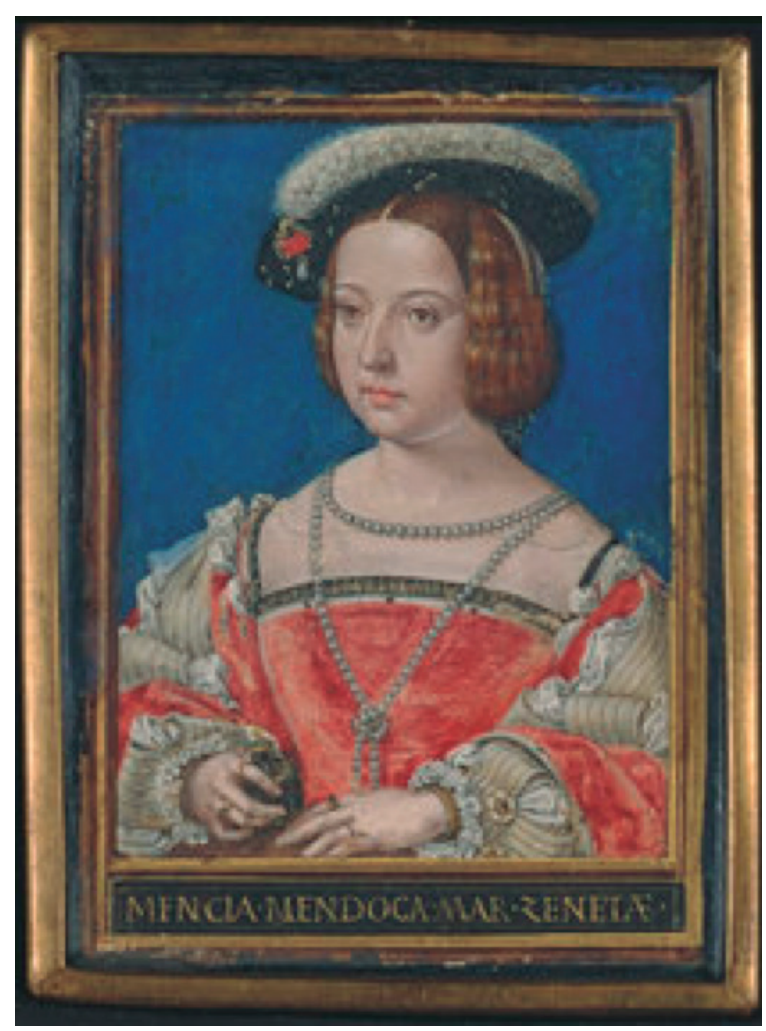

3. Mencía de Mendoza, Marchioness of Zenete, Countess of Nassau, by Simon Bening, (c) bpk / Gemäldegalerie, SMB (Berlin) / Jörg P. Anders 
In I530 Mencía de Mendoza travelled back and forth between Spain and Flanders, where she became a patron of painters, such as Jan Gossaert and Van Orley, and made the acquaintance of humanists, such as Erasmus and Joan Lluís Vives (Vosters 2007). When her husband died in 1538 she returned to Valencia, and in I54I she married the Viceroy of Valencia, Fernando de Aragón (I488-I55O), Duke of Calabria. He was the eldest son of King Ferrante of Naples and his second wife Isabel de Bancio, and the widower of Germana de Foix, King Fernando's second wife. She became very obese in her old age and died without issue in $\mathrm{I} 554$.

The second daughter, Catalina de Mendoza (I5O9-I526), married Juan de Tovar, Marquis of Berlanga, second son of Íñigo de Velasco, Constable of Castile, but she died young without issue. The third daughter, María de Mendoza (I5I3-I554), in I534 married Diego Hurtado de Mendoza (d. I566), Count of Saldaña, the eldest son of Íñigo López de Mendoza, IV Duke of El Infantado, and through this marriage the Marquisate of Zenete was eventually united with the Duchy of El Infantado.

La Calahorra, the palace that the Marquis of Zenete rebuilt as a gift for María de Fonseca, is the best expression of his personality and his greatest legacy, and it is by studying this house that new facts about his life and character have come to light. ${ }^{33}$ The sole entrance to the palace is decorated with his coat-of-arms, with the Mendoza motto Ave Maria gratia plena. Round the upper gallery his wife's coat-of-arms are displayed twice, with the words VXORIS MVNVS, 'the wife's gift', indicating that the palace is his gift to her, and that she, as well as Christ's mother, is the María whom he intends to praise. This interpretation is confirmed by a quotation from Ovid above one of the doorways on the ground floor: RARA QVIDEM VIRTVS QVAM NON FORTVNA GVBERNAT, 'Rare indeed is the virtue not governed by Fortune [which remains on steady feet when Fortune flees]' (Tristium Liber $V$, xiv, line 29). ${ }^{34}$

This line comes from an elegy addressed by the poet to his wife Fabia in the year 8 CE when he had been banished from Rome to Tomis on the Black Sea by the Emperor Augustus. This poem expresses, it would seem, the same sentiments felt by the marquis, who, like Ovid, endured a species of exile and sought through art to immortalise the irreproachable virtue and loyalty of the woman whom he loved. For Ovid his poetry is the best memorial (monumenta) that he is able to give to his wife. After reminding his wife that she is the sole custodian of his estate, he says that the accusations levelled against him have cleared a space on which her virtue can build a structure that will be visible to everyone, and he praises her for loyally standing by him: "Cum deus intonuit, non se subducere nimbo, id demum est pietas, id socialis amor" ("When the god thunders, not to avoid the cloud- that is loyalty indeed, that is wedded love'). He ends by listing some famous examples of wives renowned for their loyalty in adversity, including the wife of the hero descended from Phylacos, "whose swift foot first touched the soil of Ilium", in other words Laodamia, wife of Protesilaus. The verb gubernare means literally 'to steer a ship', and the image of Fortune, associated with the sea and storms, also finds its expression in the figure of a blindfolded girl, combining classical and medieval iconographic attributes, that formerly adorned a niche on one side of a doorway in the Salón de los Marqueses. The girl is standing in a small ship with a monstrous figurehead, with a sail billowing behind her. She clutches the rigging with one hand and holds the cornucopia, or horn of plenty, in the other (see fig. 4).

33. I here draw heavily on the research done by Margarita Fernández (I992).

34. The great Nikolaus Pevsner (Games ed. 20I4: 453), whose packed lectures on Victorian architecture I used to attend when I was a student at Cambridge, spotted this inscription when he visited La Calahorra in the ig6os. This doorway has now been transferred to the Palacio del Duque del Infantado in Madrid (León Coloma 2OII: 394 fig. 5). My translation is based on the Loeb Classic Library Series edition. 


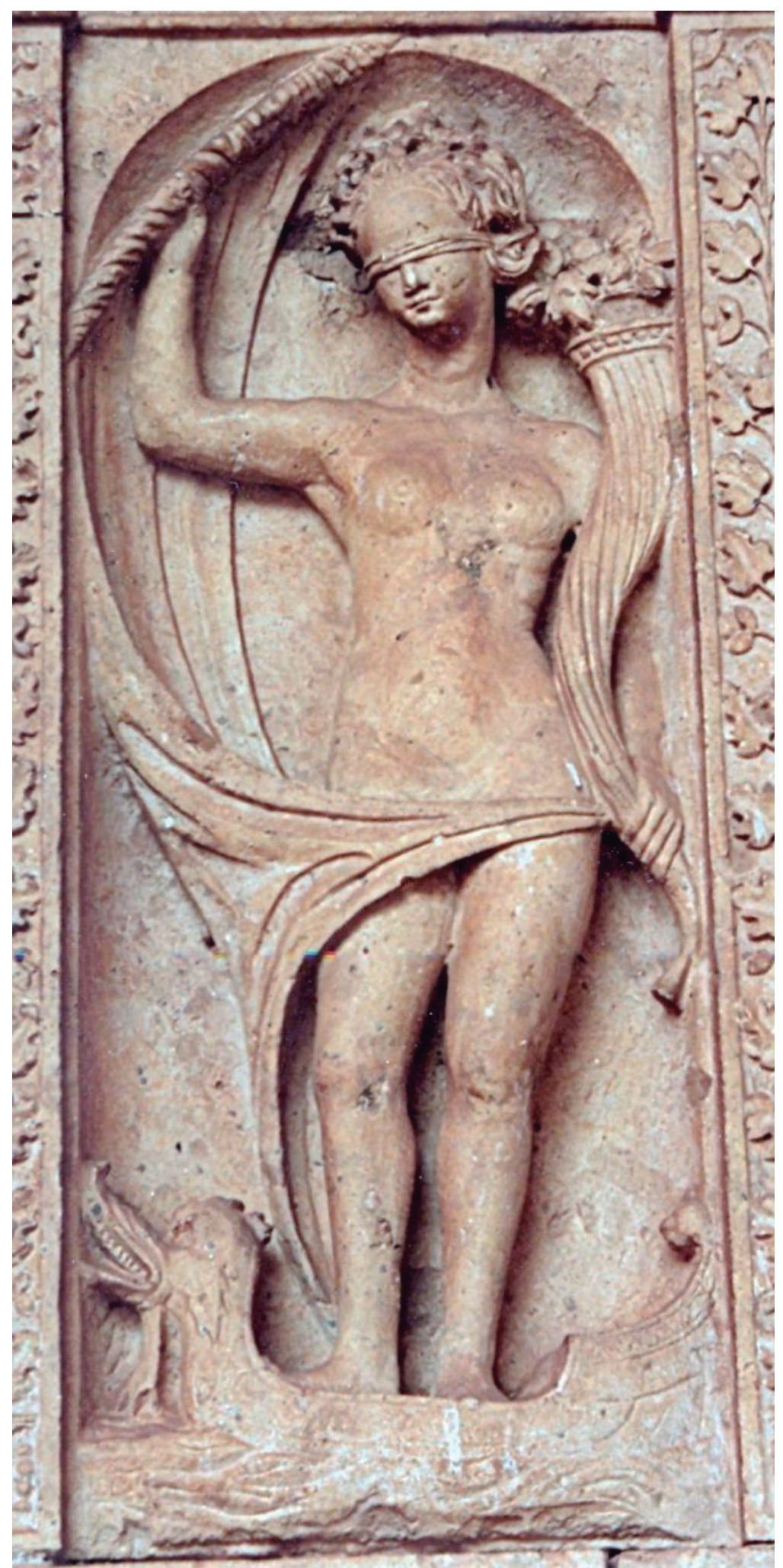

4. Fortuna, formerly in the Palace of La Calahorra, (c) Miguel Ángel León Coloma 
The cornucopia, which is a symbol of hedonistic abundance, could be regarded as a kind of chalice, the emblem displayed by Margarita de Lemos, who was the Marquis of Zenete's aunt. ${ }^{35}$ Note also that Ovid's poem, part of which is cited on the palace wall, contains the line: vela damus, quamvis remige navis eat ('we give sails to a ship that is already under oars'). All this suggests that the marquis wished to convey the message that his wife was not entirely a passive victim of Fortune, but a person who was prepared to follow the advice given by Ficino and later by Machiavelli that one should conspire with Fortune by accommodating oneself to changing circumstances (León Coloma 2OII: 39I).

There is an inscription round the upper gallery that is inspired perhaps by the example of the Alhambra Palace where Qur'anic verses in praise of God form the chief decoration.

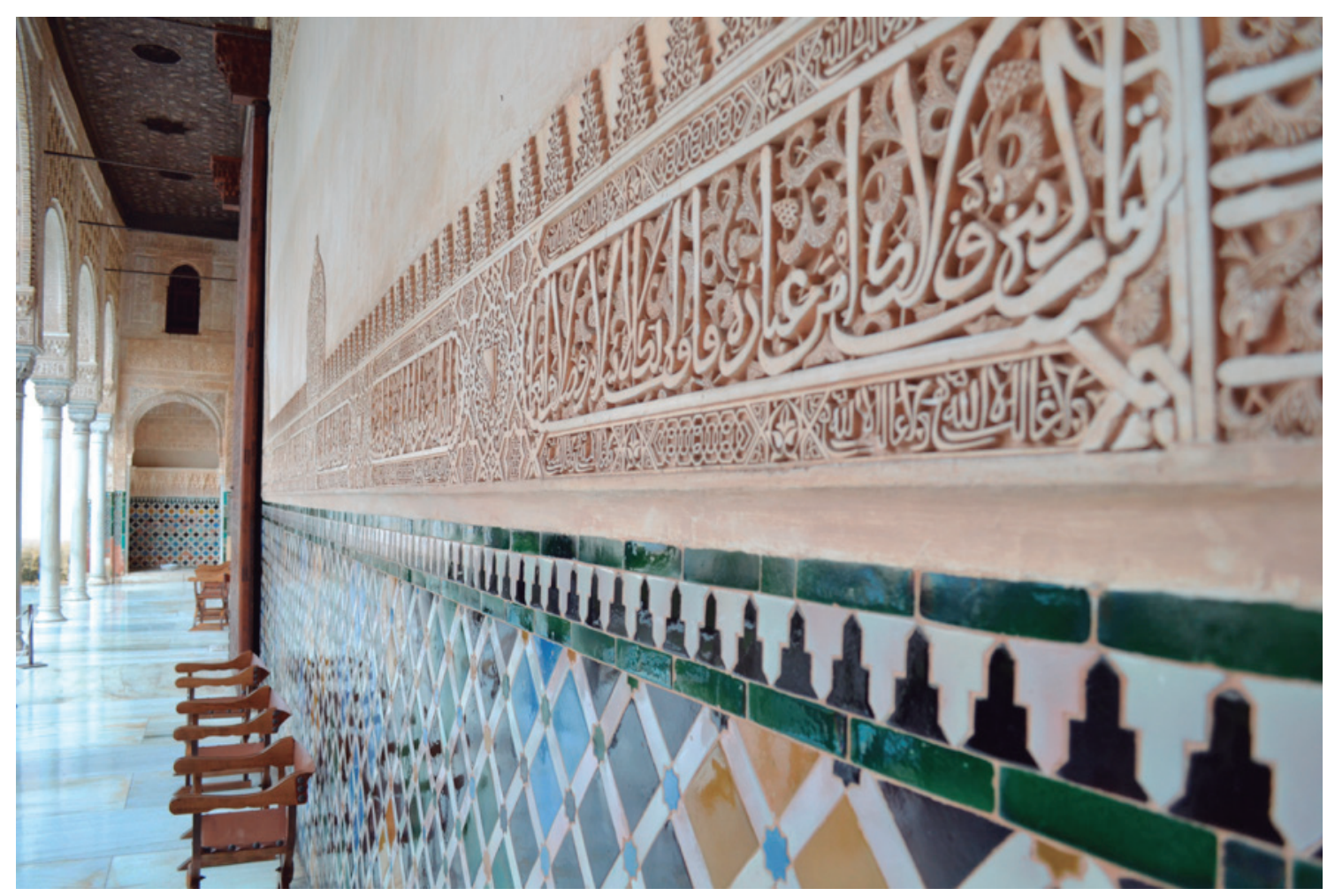

Fig. 5. Qur’anic Calligraphy, Court of the Lions, Alhambra Palace, Granada, CC-BY-NC-ND Matt Veigl [https://veigladventuretime.files.wordpress.com/2013/05/dsc oozo.jpg]

The text decorating La Calahorra comprises three verses in Latin from three different Psalms, which have been joined together with slight alterations:

\section{DOMINE ANTE TE OMNE DESIDERIVM MEVM ET GEMITVS MEVS A TE NON SIT ABSCONDITVS. FIAT MISERICORDIA TVA SVPER NOS QVEMADMODVM SPERAVIMVS IN TE. MAGNIFICATA EST ENIM VSQ[UE] AD C[A]ELOS ET VERITAS TVA IN ETERNVM.}

These verses, drawn from the Vulgate, from Psalm 37: IO, Psalm 32: 22, and Psalm 56 : II, may be translated as follows:

35. This will be discussed in Boase 2OI7. 
O Lord, all my desire is before Thee, and may my groaning be not hid from Thee. May thy mercy be upon us, for our hope is in Thee. For it has been exalted even to the heavens, and thy truth shall be forever.

The first verse comes from the third of the seven penitential psalms that are recited during the Season of Lent, and the only modification here is the very correct use of the subjunctive sit, instead of est, to express a wish that the worshipper's laments may be heard by God. In the second verse the word domine, before the preposition super, is omitted because, when joined to the first verse, it is redundant. The third verse has been pared down to stress the theme of God's mercy and to make it fit the space available, although the conjunction enim has been added to supply a link to the preceding verse, and the phrase in eternum has been inserted to round it off. These changes can be better understood by citing the version of Psalm 56 : II:

\section{Quoniam magnificata est usque ad caelos misericordia tua, et usque ad nubes veritas tua}

(For thy mercy is exalted above the heavens, and thy truth unto the clouds.)

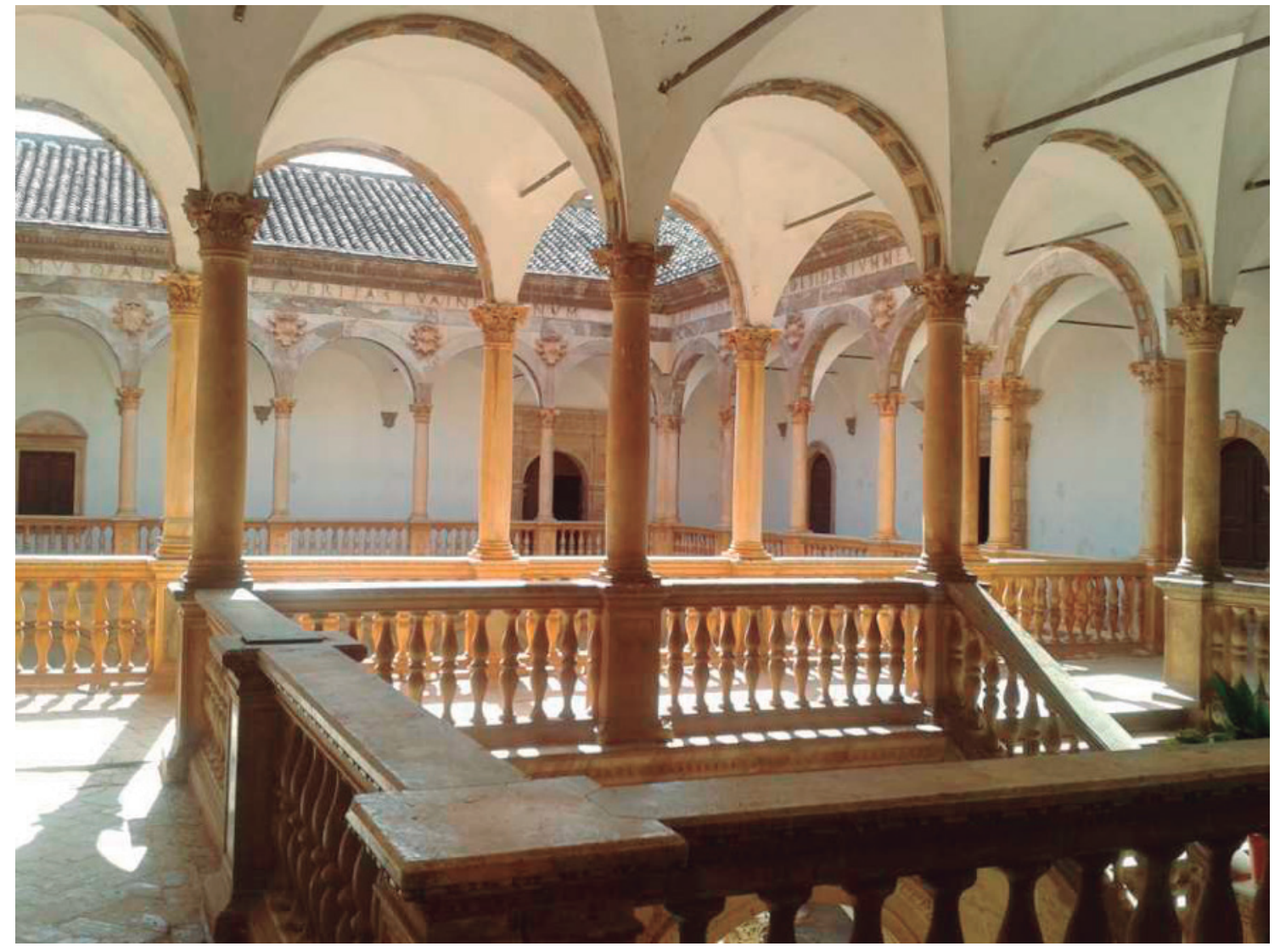

Fig. 6. Inner Courtyard of the Palace of La Calahorra, CC-BY-NC-ND Massimo [https://castlesintheworld.files. wordpress.com/20I4/OI/castello-di-la-calahorra8.jpg]

The tone of these three verses is not that of a penitent sinner, but of a man who feels ill-used, and who demands that the truth be known and justice done. Cardinal Mendoza's biographer Salazar de Mendoza (I625: I, 25I) mentions that formerly there had been an inscription in Castilian that the Marquis of Zenete had been obliged to remove. This, he says, had already been chipped off the wall 
before the arrival of the royal magistrate (alcalde de la corte) who had come to inspect it:

\section{ESTA FORTALEZA SE LABRO PARA GUARDA DE LOS CAVALLEROS A QUIEN LOS REYES QUISIEREN AGRAVIAR}

(This fortress was built as a refuge for those knights whom the monarchs may wish to offend.)

The Marquis of Zenete's cousin, Íñigo López de Mendoza, II Count of Tendilla, wrote to Luis de Pareja on 20 April I5I3, advising him to inform Antonio de Fonseca, Lord of Coca, that the marquis was planning to build two houses, one in Granada and another in Coca,$^{36}$ similar to La Calahorra and with the same inscriptions, but he adds that this should be said jokingly so as not to irritate him. ${ }^{37}$ An earlier letter addressed by the Count of Tendilla to Hernando de Vega, Comendador mayor de

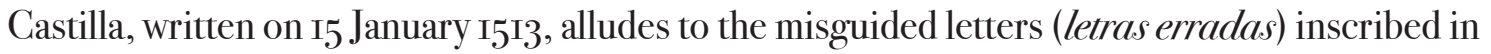
marble, warning that they might cause damage when they were removed (Meneses García I973-74: II, I4I).

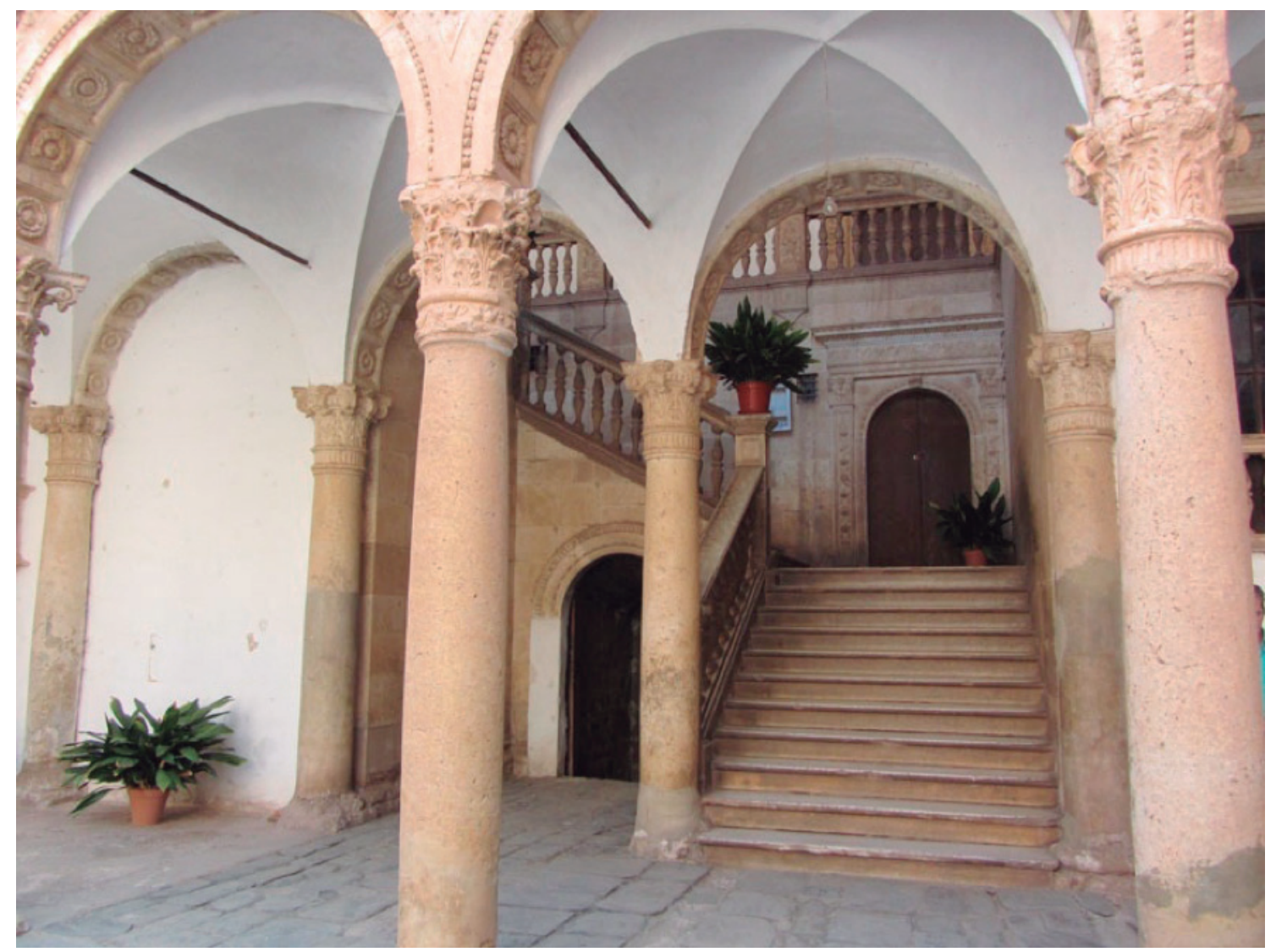

Fig. 7. Stairway of Genoese Craftsmanship, Palace of La Calahorra, CC-BY-NC-ND Antonio Díaz Perea, 9 June 2015.

36. This name is wrongly transcribed as Coratal by Meneses García (Marías i99o: 225 n24). No such place name as Coratal exists.

37. "A Fonseca hablalle como a señor y hermano mío mayor y velle muchas vezes en su casa. Y hablarle en el marqués y en sus locuras, y como agora dize que ha de hazer dos casas, una en Granada y otra en Coratales [Coca], como la de La Calahorra, y creo que querrá poner las mismas letras. Esto se dirá burlando dél como de loco, porque no se afrente Fonseca" (Meneses García 1973-74: II, 267). 
It is said that formerly there had been another inscription in Latin between the upper and lower floors of the courtyard, which had also been removed. ${ }^{3}{ }^{8}$ Whether or not it is apocryphal, the text composed c. I5IO in the elegant humanistic style of the Count of Tendilla sheds some light on the Marquis of Zenete's much disputed date of birth:

MARCHIO D. RODERICVS DE MENDOZA PRIMVS ANNO MILL.MO QVINGENTISSIMO
DECIMO PROPRIO TRIGESSIMO SEPTIMO HANC IVSSIT DOMVM INSTRVI. NEC TAMEN
EI COLENDAM OCCIO SED ILLICITO COMPVLSVS FVISSET CVM HISPANIAE NOSTRAE
INFELICIS GUBERNATVS EA TEMPESTATE FVGIENDVS RECEPTVS HOC GRUMULO SIC
PAVLVM VAGARI LIBVIT LONGIVS DVM PETERE ALII NEC LICERET INTENDERE.

(The first marquis, Rodrigo de Mendoza, in the year $5_{5}^{\mathrm{IO}}$, at the age of thirty-seven, ordered this house to be built. Yet he did not build it to cultivate his own solace but because he was unjustly compelled to do so. Since he had to flee from the storm of the unhappy government of our Spain, he took refuge on this hilltop. Thus it pleased him to wander a little longer while he was not permitted to pursue, or attempt to attain, anything else.)

If the marquis was thirty-seven years of age in $\mathrm{I}_{5} \mathrm{IO},{ }^{39}$ this means that he was born in $\mathrm{I} 473$, whereas it is traditionally claimed that he was born in I 466 or even I 459 (Meneses García I973-74, I, I49). Margarita Fernández (1992: 52) is convinced that there must have been an error in the transcription of the Roman numerals. But it should be stressed that it was in the interests of the ecclesiastical establishment to accept early dates of birth for all Cardinal Mendoza's 'bellos pecados', and it is significant that when, in $5_{580}$, the Order of Santiago carried out an investigation into the pedigree of Diego de Mendoza y Fernández Manrique, the Marquis of Zenete's grandson, the Archbishop of Toledo Gaspar de Quiroga declined to provide details (Catalina García I899: 679 n4). Recent research, notably by Falomir Faus and Marías (1994), confirms that the cardinal's eldest son was indeed born in I473, towards the end of his tenure as Bishop of Sigüenza (I467-I474).

First of all, it is evident from Fernández de Oviedo’s Batallas y quinquagenas (ms. 359, f. 862) that the future marquis was only sixteen years of age when he fought at the siege of Baza in I489. In the words of his biographer, he was then "muy mozo y de poca edad y experiencia en la guerra de los moros" (Medina y Mendoza I853: 284). Secondly, he was brought up at the court of Prince Juan, who was born in $\mathrm{I}_{47} \mathrm{8}$, and therefore he could not have been so much older than the prince. Thirdly, it would make more sense if he were approximately the same age as his first wife, who was born in I $47^{2}$. Finally- and this is the most compelling evidence- it is almost certain that the medal that he had made at the age of twenty-six, depicting Mars and Venus, was not minted in I 49I at the time of his investiture as Marquis of Zenete, as previously thought, nor in I 494 to mark the birth of his son Luis, who died as an infant, as suggested by Marías (I990: 52), but in I 499 when he visited Rome, because it is almost identical in style to one made in that year for Bernardino López de Carvajal (I456-I523), Ambassador to the Vatican and Cardinal of Santa Croce in Jerusalem (Falomir Faus-Marías 1994: IO7), all of which serves to demonstrate that the marquis was born in I 473 and that his birth occurred after Roderic de Borja, the future Pope Alexander VI, visited Valencia, Aragon and Castile in I472. This was a period of shocking extravagance and sexual permissiveness, coinciding with civil war and famine, when Cardinal Mendoza, who was then Bishop of Sigüenza,

38. This inscription is cited in a letter, mentioned by Gómez-Moreno ( $1925: 38)$, which has been misplaced and is not included in the edition of the Count of Tendilla’s correspondence by Meneses García (Marías 1990: 125).

39. As Gómez-Moreno notes (1925: 36), this year is historically inaccurate because the construction of the Renaissance courtyard began in I5O9. It is possible that he regarded the numbers IO and 37 as more numerologically significant: Io is the sum of 3 and 7 . It may also have been his intention to prove that the palace had been completed in only three years. 
sought to emulate the papal legate by organising splendid banquets for him, such as one in Valencia on 25 October when seven dishes, each carrying partridges, and two peacocks with gilded heads out of whose beaks perfumed water flowed, were introduced with a fanfare of trumpets (Sanchis y Sivera 1924: 15I). Furthermore, it was Cardinal Mendoza's task to arrange for Roderic de Borja’s huge retinue to be lodged and lavishly entertained when in I 473 he visited Castile, prompting an anonymous poet to satirise the occasion in a grotesque and Rabelaisian work: the Aposentamiento que se hizo en Juvera (ID 2999, IICG-965).
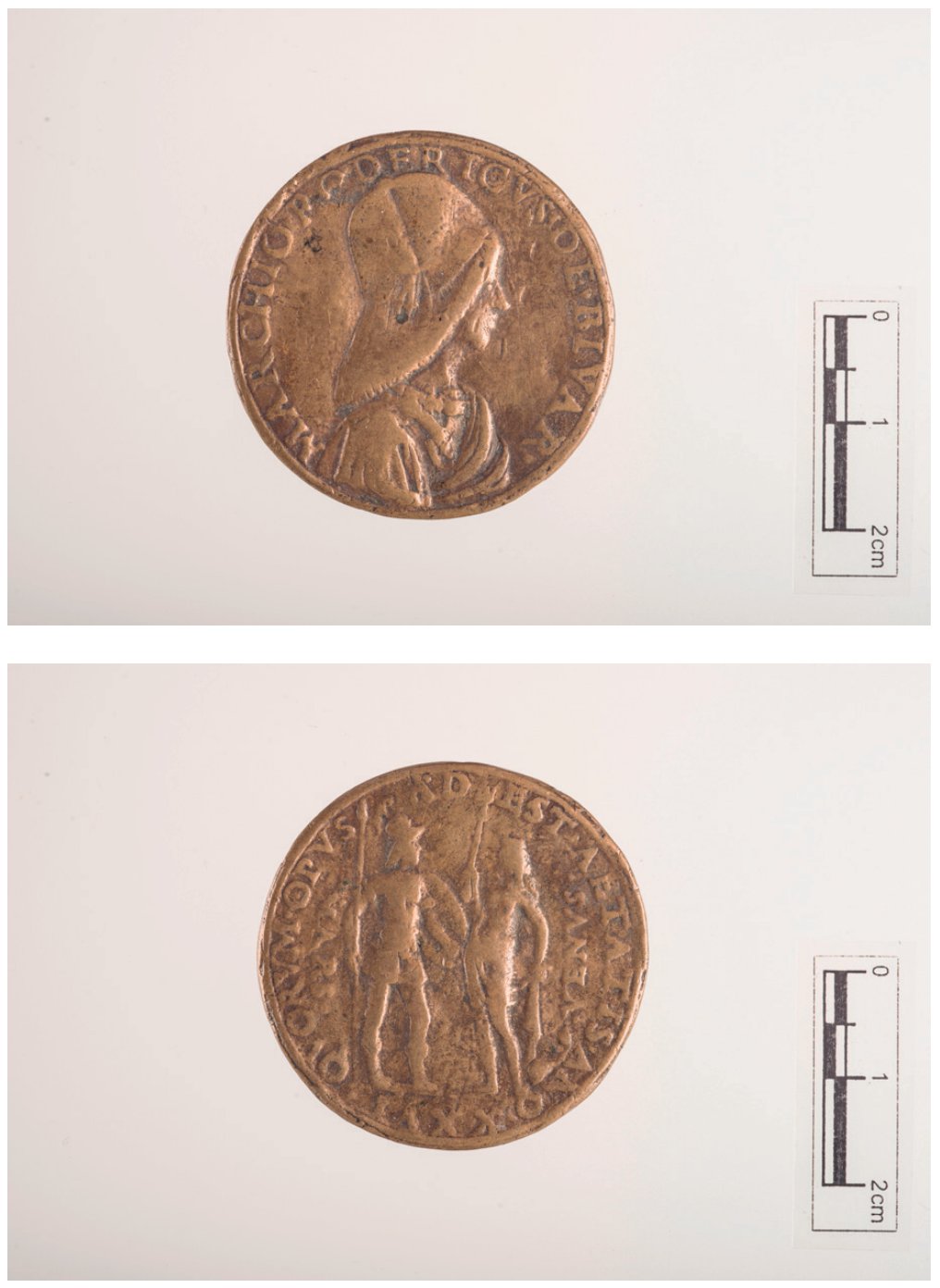

Figs 8-9. Medallion of the Marquis of Zenete, with Mars and Venus, (C) Museo Arqueológico Nacional (Madrid) /Ángel Martínez.

The Latin inscription QVORVM OPVS ADEST AETATIS ANNO XXVI means that he who is depicted on the obverse of the medallion and is twenty-six years of age, namely MARCHIO RODERICVS DE BIVAR, is the adulterous offspring of Mars and Venus. This shows that the marquis was conversant with the Greek legend, discussed by Plutarch in his essay on Isis and Osiris, that Harmony was the child of Mars and Venus, and that he also knew about Pico della Mirandola's definition of beauty as a union of opposites, or discordia concors (Wind I967: 88; cf. figs. 78-79). The medallion was thus a way of 
giving to the circumstances of his birth an almost metaphysical significance..$^{\circ}$

There is one final discovery about María de Fonseca and her sister that should be mentioned. It has not been hitherto noticed that the two sisters figure in the Carajicomedia, an anonymous and highly obscene work completed shortly before, or shortly after, King Fernando's death in ${ }_{5} 5^{16}$ and published in Valencia by Juan de Viñao in I5I9. Here, in this parody of Juan de Mena's Laberinto de Fortuna, they are identified as natives of Toro residing in Valladolid, and they, like all the other women in this satire on the ladies of the royal court, are portrayed as if they were prostitutes (Varo ed.r981: I8I):

Dos ermanas son Fonsecas, naturales de Toro. Residen en Valladolid. Son gentiles mugeres, especialmente esta menor, de quien habla el autor. La cual tiene por amigo al Prior de la Merced, que en tanto grado la quiere que las paredes del monasterio desuella para dalle.

(There are two sisters, Fonsecas, natives of Toro. They live in Valladolid. They are noble women, especially this younger one, about whom the author speaks, whose friend is the Prior of La Merced, who loves her so much that he fleeces the walls of the monastery to give to her.)

The focus, in stanza 46 , is on the younger woman, la menor Fonseca, whose name, paradoxically, is a clue that her name is in fact Mayor:

La menor Fonseca me fue demostrada

y ell Olimpo frayle qu'en ella resede,

la qual en hoder las nuves ecede,

por do la Merced ya está desolada.

Maguer muy hermosa, está sovajada,

del cabez mordido, nefando tirano,

que ruego a Dios me venga a la mano,

porque mi alma d'él sea vengada.

(The younger Fonseca was shown to me / and the Olympian friar who dwells in her, / she who in fucking surpasses the clouds, / through whom already the Merced monastery has been fleeced. / Although very beautiful, she has been roughly handled / by the base tonsured tyrant, / whom I pray to God may be placed in my grasp / so that my soul may be avenged on him.)

In his commentary, the nar rator claims that he chanced to meet Mayor de Fonseca one night, at about ten o'clock, as she was on the point of entering the Merced convent by a secret door to visit the Prior, "imitating the example of her saintly ancestors". The narrator recognised Mayor de Fonseca and she begged him not to follow her, telling him to meet her at her lodgings. Having kissed her hand, he returned home, and after that, he says, great things came to pass between the two of them. It needs to be said, however, that Mayor was a lady with a taste for learning and literary pursuits and therefore her motives for frequenting the clergy may not have been necessarily or exclusively amatory. During this period the Mercedarians were keen to promote scholarship, and the Convento de la Merced in Valladolid had received an endowment from Rodrigo de Villandrando (I475), I Count of Ribadeo, that was used to fund five places for students of theology and canon law at the universities of Salamanca and Valladolid (Vázquez Núñez 1932: 157; Taylor 2000: 63). The Prior of the Convento de la Merced in Valladolid at this time was Fray Antonio de Valladolid,

40. His own collection of books included works by Hermes Trismegistus, Plotinus and Ficino (Lleó Cañal I993: I $75-76)$. 
who was a chaplain to the Catholic Monarchs and Provincial of the Mercedarian Order in Castile, Portugal and Granada during the years I493-I5O4 (Vázquez Núñez ı923: ıı6, and I93ı: 395). In her will, drawn up at Salamanca and Coca, on 3 and I5 May I53, Mayor gave instructions for the funding of a professorship in Latin grammar, poetry and rhetoric, established by her father in Coca (Rodríguez Martínez 20Io: 267-74). It was also at this same time that she and her husband sponsored the initiative of Fray Domingo de Valtanás to found a Dominican convent at La Guardia, near Jaén.

Note that the anonymous author, in praising María de Fonseca's sister- "la qual en hoder las nuves ecede", or usque ad nubes-alludes to the same passage from Psalm 56 , verse II, that can still be seen displayed on the walls of La Calahorra where the heavens are mentioned, but not the clouds. It is likely that the anonymous author spared María de Fonseca from the barbs of his cruel humour because it was well known that she and her husband had some sympathy for the comuneros in Castile and the agermanats in Valencia who were calling for radical social reforms and whose ideas eventually resulted in a popular revolt against an increasingly repressive and absentee monarchy in the years I52O-I522. The marquis remained throughout his life something of a rebel, which is why, just as King Fernando had forbidden the marquis from entering Granada in the years I5O8-I5I3, so the Emperor Charles V, in a letter from Ghent, dated II June I520, had given similar instructions to Diego de Mendoza, Count of Mélito, to expel his brother from Valencia and to give him three days' notice to quit the city, ${ }^{41}$ instructions that were in fact never implemented. 


\section{Works Cited}

Alcedo y de San Carlos, Marqués de. 1926. Un pleito olvidado del siglo XV: la herencia de Suero de Quiñones (Madrid: Blass)

Aliaga, Joan; Company, Ximo; Tolosa, Lluïsa; Puig, Isidre; Ramon, Núria; Rusconi, Stefania; Franco, Borja. 20I4. 'The Medieval and Modern Investigation Centre (CIMM): Documentary Contributions', Imago Temporis Medium Aevum, 8: 329-56 <http://www.medieval.udl.cat/ medieval/sites/default/files/files/Imago8.pdf>

Anderson, Ruth Matilda. 1979. Hispanic Costume 1480-153o (New York: The Hispanic Society of America)

Andreoli, Massimiliano (ed.). 2005. Quirós Poesie (Napoli: Liguori) Romanica Neapolitana, 36

Arteaga y Falguera, Cristina. 1970.'El castillo de Calahorra, último balauarte de los Mendoza', Castillos de Castilla, 69:4-5

Avalle-Arce, Juan Bautista (ed.). I989. Gonzalo Fernández de Oviedo Batallas y quinquagenas (Salamanca: Diputación Provincial) Lengua y Literatura, 4

Avalle-Arce, Juan Bautista. 1992. 'Sobre un romance noticiero', Nueva Revista de Filología Española, 40: 1I7-30

Batallas Avalle: vid. Avalle-Arce ed. 1989

Batallas RAH: vid. Pérez de Tudela ed. 2002

Beceiro Pita, Isabel; Córdoba de la Llave, Ricardo. I99o. Parentesco, poder y mentalidad: la nobleza castellana, siglos XII-XV (Madrid: CSIC)

Boase, Roger. 20o6. 'Alfonso V of Portugal and Isabel of Castile: Poetry for the young princess? (LBI-I92-2OI, folios 62r-64v)', in Convivio: estudios sobre la poesía de cancionero, ed. by Vicenç Beltran, Juan Paredes (Granada: Universidad de Granada), pp. 227-39

Boase, Roger. 20I7. Secrets of Pinar's Game: Court Ladies and Courtly Verse in Fifteenth-Century Spain (Leiden: Brill)

Boix, Vicente. 1867. Crónica de la provincia de Valencia (Madrid: Rubió y Compañía) < http://bvpb. mcu.es/es/consulta/registro.cmd?id=454994 $>$

Brooke, Christopher N. L. 1989. The medieval idea of marriage (Oxford: OUP)

Canellas López, Ángel (ed.). I988-9o. Jerónimo Zurita Anales de Aragón, vols. 7-8 (Zaragoza, Institución Fernando el Católico) <http://ifc.dpz.es/publicaciones/ver/id/2448 >

Carriazo, Juan de Mata (ed.). 1943. Fernando del Pulgar, Crónica de los Reyes Católicos, Madrid, Espasa-Calpe (CCE, 5-6), 2 vols

Catalina García, Juan. I899. 'El segundo matrimonio del primer Marqués del Cenete', in Homenaje a Menéndez y Pelayo en el año vigésimo de su profesorado, vol. 2, ed. by Juan Valera (Madrid: Librería General de Victoriano Suárez), pp. 665-8I < $\underline{\text { https://archive.org/details/ }}$ homenajemenndeo2menuoft>

Cooper, Edward. 1991. Castillos señoriales en la Corona de Castilla (Salamanca: Junta de Castilla y León) 3 vols. in 4 
Córdoba de la Llave, Ricardo. 2OII. 'El caso de María de Fonseca: un ejemplo de violencia contra la mujer en el seno de la familia', in Raíces profundas: la violencia contra las mujeres (Antigüedady EdadMedia), ed. by María Jesús Fuente, Remedios Morán (Madrid: Polifemo), pp. 329-54

Escartí, Vicent-Josep; Tordera, Antoni (ed.). 20oI. Luis de Milán El cortesano: libro de motes, de damas y caballeros (València, PUV) 2 vols

Espejo de Hinojosa, Cristóbal. r93I. 'Antonio de Fonseca y de Ayala, Señor de Casa y Alaejos, contador mayor de Hacienda', Revista de Archivos, Bibliotecas y Museos, 8: 97-302

Espinar Moreno, Manuel, et al. 1985. Documentos para el estudio del marquesado de Cenete, vol. I: 1462-1542 (Granada: Grupo Editorial Universitario)

Falomir Faus, Miguel. 1994. 'El Duque de Calabria, Mencía de Mendoza y los inicios del coleccionismo pictórico en la Valencia del Renacimiento', Ars Longa, 5: I2I-24

Falomir Faus, Miguel; Marías, Fernando. 1994. 'El primer viaje a Italia del Marqués de Zenete', Anuario del Departamento de Historia y Teoría del Arte, 6: IOI-I2O

Fantazzi, Charles; Matheeussen, Constant (ed.). I998. Joan Lluís Vives De institutione feminae christianae [I524], vols. 2 \& 3 (Leiden: Brill)

Fernández, Margarita. 1992. 'Reflexiones cronológicas sobre el palacio de La Calahorra', Ars Longa, 3: 47-53

Fernández Madrid, María Teresa. 1989. 'Los Mendoza y la arquitectura alcarreña del Renacimiento', tesis doctoral (Madrid: Servicio de Publicaciones de la Universidad Complutense de Madrid)

Fernández Madrid, María Teresa; Gómez Lorente, Manuel. 1992. 'Los bienes del marqués de Cenete en la provincia de Guadalajara (I492-I523)’, Wad-al-Hayara, I9: 231-39

Franco Silva, Alfonso. 1982. 'La herencia patrimonial del gran Cardenal de España don Pedro González de Mendoza', Historia, Instituciones, Documentos, 9: 453-490

Franco Silva, Alfonso. 1999. 'El arzobispo de Sevilla Alonso de Fonseca el Viejo: notas sobre su vida', Boletín de la Real Academia de la Historia I96, 43-92.

Games, Stephen (ed.). 20I4. Nikolaus Pevsner The complete broadcast talks: Architecture and art on radio and television 1945-1977 (Aldershot: Ashgate)

García de Paz, José Luis. 2008. 'En el centenario de Mencía de Mendoza (I5o8-I554)', El Decano de Guadalajara, 2008/II/28. Reproduced in 〈http://tinyurl.com/guk6xqy $\rangle$

García Cárcel, Ricardo. I98ı. Las Germanías de Valencia (Barcelona, Península) ed. 1975

García Carraffa, Alberto; García Carraffa, Arturo. 1929 \& I96r. Enciclopedia heráldica y genealógica hispano-americana, vols. 35 \& 84 (Madrid: Hauser y Menet)

García López, Aurelio. 1995. 'La correspondencia del conde de Tendilla: nuevos datos sobre el mecenazgo de la familia del Cardinal Mendoza', Wad al-Hayara, 22. 65-122

García Oro, José; Portela Silva, María José. 2002. Los Fonseca en la Galicia del Renacimiento: de la guerra al mecenazgo, estudio y colección (Coruña, Toxosoutos)

García Pérez, Noelia. 2004. Arte, poder y género (Madrid, Nausicaä)

García Pérez, Noelia. 2007-2008. 'Modelos de enterramiento, modelos de patronazgo: La Capilla de los Tres Reyes del Convento de Santo Domingo de Valencia y los Marqueses del Zenete’, Imafronte, I9-20: 63-74 
Gómez-Ferrer, Mercedes. 20IOa. 'Las almonedas de los libros del Marqués de Zenete en I529 y I535 en Valencia', Lemir, I4: 23I-246

Gómez-Ferrer, Mercedes. 2OIob. 'El marqués de Zenete y sus posesiones valencianas: mentalidad arquitectónica y artística de un noble del Renacimiento', Anuario del Departimiento de Historia y Teoría de Arte, 22: 27-46

Gómez-Ferrer, Mercedes; Samper, Vicente. 1995. 'Felipe Pablo de San Leocadio: aportación documental', Archivo de arte valenciano, $76:$ 52-54

Gómez Lorente, Manuel. 1990. El marquesado de Cenete (1490-1523), tesis doctoral (Granada, Universidad de Granada) <http://hdl.handle.net/IO48I/6460 $>$

Gómez-Moreno, Manuel. 1925. ‘Sobre el Renacimiento en Castilla: hacia Lorenzo Vázquez', Archivo Español de Arte y Arqueología, I: I-40

Gómez-Moreno, Manuel. I991. Sobre el Renacimiento en Castilla (Granada: Instituto GómezMoreno de la Fundación Rodríguez Acosta)

Hidalgo Ogáyar, Juana. 2005. 'El papel de la nobleza en la introducción del Renacimiento en España: nuevas aportaciones referentes a los marqueses del Zenete y los condes de Melito', in El arte foráneo en España: presencia e influencia, ed. by Miguel Cabañas Bravo (Madrid: CSIC), pp. 26I-68

Iborra, Joan (ed.). 2005. Martí de Viciana Libro quarto de la Crónica de la ínclita y coronada ciudad de Valencia y de su reino [1566] (Valencia: Universitat de València)

Joyce, George Hayward. 1948. Christian marriage: An historical and doctrinal study (London: Sheed and Ward)

Lacadena y Brualla, Ramón de. 2005. El cardenal de España: retrato del más poderoso asesor de los Reyes Católicos (Barcelona: Belacqua)

Lasso de la Vega y López de Tejada, Manuel. 1942. Doña Mencía de Mendoza, Marquesa del Cenete (1508-1514) (Madrid: Real Academia de la Historia)

Layna Serrano, Francisco. 1942. Historia de Guadalajara y sus Mendoza en los siglos XV Y XVI (Madrid: CSIC), 4 vols

León Coloma, Miguel Ángel. 2OII. 'Ovidio en el Palacio de La Calahorra: La Fortuna y el marqués del Cenete', in Emblemática trascendente: hermenéutica de la imagen, iconología del texto, ed. by Rafael Zafra Molina; José Javier Azanza (Pamplona: Universidad de Navarra), pp. 387-98

Lleó Cañal, Vicente. 1993. 'La cultura simbólica en el Renacimiento: un ejemplo de teología poética', in La cultura del Renaixement: homenatge al Pare Miquel Batllori (Bellaterra: Universitat Autònoma de Barcelona), pp. ı69-88

López-Muñoz Moragas, Gonzalo. 2003. El castillo de Jadraque (Guadalajara: Aache Ediciones)

Macpherson, Ian. 2004. Motes y glosas in the 'Cancionero General', PMHRS, 46 (London: Department of Hispanic Studies, Queen Mary University of London)

March, Esteban. 195. 'El primer marqués del Cenete: su vida suntuosa', Archivo Español de Arte, 24: $47-65$

Marías, Fernando. I99o. 'Sobre el castillo de La Calahorra y el Codex Escurialensis', Anuario del Departamento de Historia y Teoría del Arte, 2: II7-29 
Marino, Nancy F. 200I. 'How portuguese damas scandalized the court of Enrique IV of Castile', Essays in Medieval Studies, I8: 43-52 <http://dx.doi.org/IO.I353/ems.200I.0005>

Medina y Mendoza, Francisco de. I853. Vida del Cardenal D. Pedro González de Mendoza (Madrid, Real Academia de la Historia), Memorial Histórico Español, 6

Meneses García, Emilio (ed.). 1973-74. Correspondencia del Conde de Tendilla (15o8-1509) (Madrid: Real Academia de la Historia) Archivo Documental Español, 3I, 2 vols

Mérimée, Henri (ed.). I9O7. Gaspar Mercader El prado de Valencia (Toulouse: Faculté des Lettres de Toulouse)

Morrás, María (ed.). 2003. Jorge Manrique Poesía, Clásicos Castalia, 27I (Madrid: Castalia)

Núñez de Castro, Alonso. I653. Historia eclesiástica y seglar de la muy noble y muy leal ciudad de Guadalaxara (Madrid: Pablo de Val) < http://tinyurl.com/gtqowpr $>$

Perea Rodríguez, Óscar. 2007. Estudio biográfico sobre los poetas del Cancionero General (Madrid, CSIC)

Pérez de Tudela y Bueso, Juan (ed.). 1983-2002. Gonzalo Fernández de Oviedo, Batallas y quinquagenas (Madrid: Real Academia de la Historia), 4 vols

Prieto Cantero, Amalia. 1969. Casa y descargo de los Reyes Católicos: catálogo XXIV del Archivo General de Simancas (Valladolid: Instituto Isabel la Católica de Historia Eclesiástica)

Puyol, Julio (ed.). 1934. Crónica incompleta de los Reyes Católicos (1469-1476) según un manuscrito anónimo de la época [by Juan de Flores] (Madrid: RAH)

Ramos Santana, Carmen. 200o. 'Una biografía desconocida de Lucio Marineo Sículo: el ms. 9/5962 de la Real Academia de la Historia', Calamvs Renascens, I: 3II-29

Río Nogueras, Alberto del. 1994. 'Libros de caballerías y poesía de cancionero: invenciones y letras de justadores', in Actas del III Congreso de la Asociación Hispánica de Literatura Medieval,

Salamanca 1989, vol. I, ed. by María Isabel Toro Pascual (Salamanca: Universidad de Salamanca), pp. 303-18

Rodríguez Martínez, Felipe. 20Io. Corpus documental de Coca (Madrid: Visión Libros)

Rodríguez Puértolas, Julio, ed. 1987. Fray Ambrosio Montesino Cancionero (Cuenca, Diputación Provincial de Cuenca)

Rodríguez Villa, Antonio. I896. 'Don Francisco de Rojas, embajador de los Reyes Católicos', Boletín de la Real Academia de la Historia, 28: I80-202, 295-339, 364-402, 440-474

Ruiz Hernando, J. Antonio. 1982. Historia del urbanismo en la ciudad de Segovia del siglo XII al XIX, (Madrid: Diputación Provincial de Segovia), 2 vols

Ruiz Pérez, Ricardo. 20I4. 'La construcción del castillo-palacio de La Calahorra (Granada): fuentes, causas y nuevas aportaciones a propósito del V centenario', Revista Electrónica del Centro de Estudios Históricos de Granada, 26: 167-200

Sales Dasí, Emilio J. r999. 'Garci-Rodríguez de Montalvo, regidor de la noble villa de Medina del Campo', Revista de Filología Española, 79: 123-58 <http://dx.doi.org/IO.3989/rfe.I999.v79. iI $/ 2.32 \mathrm{I}>$

Salazar de Mendoza, Pedro. I625. Chrónica de el gran cardinal de España don Pedro González de Mendoza (Toledo: En la Emprenta de doña María de Ortiz de Saravia) < $\underline{\text { http://tinyurl.com/ }}$ 
$\underline{\text { zrbls64 }}>$

Sánchez Cantón, Francisco Javier. 1942. La biblioteca del Marqués de Cenete: iniciada por su padre el Cardenal Mendoza (1470-1523) (Madrid: CSIC)

Sánchez Martín, Aureliano (ed.). I994. Diego Enríquez del Castillo Crónica de Enrique IV (Valladolid: Universidad de Valladolid)

Sanchis y Sivera, José. 1924. 'El Cardenal Rodrigo de Borja en Valencia', Boletín de la Real Academia de la Historia, 84: 120-64 < http:// www.cervantesvirtual.com/obra/el-cardenalrodrigo-de-borja-en-valencia/>

Sitges, Juan Blas. 1912. Enrique IV y la Excelente Señora llamada vulgarmente Doña Juana la Beltraneja, 1425-1530 (Madrid: Sucesores de Rivadeneyra)

Tapia Sánchez, Serafín. 2009. 'Alí Caro, Alarife', in Historia de Avila vol. 4: Edad Media: siglos $X I V-X V$, segunda parte, ed. by Gregorio del Ser Quijano (Ávila: Ediciones de la Institución Gran Duque de Alba)

Taylor, Bruce. 2000. Structures of reform: The Mercedarian order in the Spanish Golden Age (Leiden, Brill)

Tristán García, Francisco. 2007. ‘Enrique Enríquez, el primer repoblador de los Reyes Católicos’, in Los señoríos en la Andalucía moderna: el marquesado de los Vélez, ed. by Francisco Andújar Castillo and Julián Pablo Díaz López (Almería: Instituto de Estudios Almerienses), pp. 58I-6o3

Varo, Carlos (ed.). 198I. Carajïcomedia: texto facsimilar (Madrid: Playor)

Vasallo Toranzo, Luis. 2OI4. 'El Castillo de Coca y los Fonseca: nuevas aportaciones y consideraciones sobre su arquitectura', Anales de Historia de Arte, 24: 6I-85

Vázquez Núñez, Fray Guillermo. I923. 'Los provinciales de la Merced de Castilla’, Boletín de la Orden de la Merced, II: III-I?

Vázquez Núñez, Fray Guillermo. 193I. Manual de historia de la orden de Nuestra Señora de la Merced (Toledo: Editorial Católica Toledana)

Vázquez Núñez, Fray Guillermo. 1932. 'Conventos de la orden de la Merced', Boletín de la Orden de la Merced, 20: $135^{-7}{ }^{2}$

Vega Vázquez, Isabel (ed.). 20o6. El libro de motes de damas y caballeros de Luis de Milán (Santiago de Compostela: Universidade de Santiago de Compostela)

Verrua, Pietro. 19o6. Cultori della poesia latina in Ispagna durante il regno di Ferdinando il Cattolico: note desunte dalle opere di Lucio Marineo Siculo (Adria: Tipografia Vidale) < https:// archive.org/stream/cultoridellapoesooverr/cultoridellapoesooverr_djvu.txt $>$

Vilches Vivancos, Fernando. 1995. 'El cardenal Mendoza: la familia, la vida, el personaje’, Wad-alHayara, 22: 17-36.

Vosters, Simon A. 2007. La dama y el humanista: Doña Mencía de Mendoza y Juan Luis Vives entre Flandes y Valencia (Madrid: Nausicaä)

Wind, Edgar. 1967. Pagan mysteries in the Renaissance (Harmondsworth: Penguin), I ed. $195^{8}$

Zalama, Miguel Ángel. 1990. El palacio de La Calahorra: primer edificio del Renacimiento en España, Granada, Caja General de Ahorros de Granada 